\title{
EXCAVATIONS AT KITION-BAMBOULA 1879 Finds in the British Museum
}

\author{
Thomas KIELY and Sabine FourRIER
}

\begin{abstract}
OVERVIEW (T.K.)
In 1880, the Trustees of the British Museum were presented with a group of objects discovered the previous year during the partial demolition of a large artificial mound known as the Bamboula in Larnaka. The partial destruction of this feature - now known by scholars to have contained the remains of a major religious, commercial and military quarter of the ancient city of Kition (including the Cypro-Classical period war harbour with its impressive shipsheds) - is well known in the historiography of Cypriot archaeology. In many respects it reflects the inchoate and at time chaotic nature of archaeological activity on the island prior to the development of the modern discipline, but also illustrates the highly pragmatic priorities of the new British authorities. The discoveries made in 1879, described in a highly schematic and unsatisfactory manner in a number of surviving contemporary accounts, have been elucidated by modern archaeological work in the area, especially by the French expedition since 1976. By contrast, the finds presented to the British Museum have never been published in a comprehensive manner. Some are important in their own right, including several previously unknown objects, while as a group they complement similar finds from scientifically-excavated contexts at Bamboula. The chief aim of this article is to provide a catalogue raisonné of all the finds that can still be identified in the British Museum collections. This is provided by Fourrier in the main section of the paper below. By way of introduction to this catalogue, Kiely re-examines the background to the original excavations and provides additional commentary on existing studies of the documentary material.

When Britain occupied Cyprus in 1878, it took possession of what was in many respects an under-developed territory, particularly in terms of public infrastructure. Roads, bridges, harbours, irrigation and sanitation were in urgent need of improvement, a problem noted by contemporary observers debating the merits of this latest addition to the
\end{abstract}


British Empire. ${ }^{1}$ These problems posed a serious hurdle to its use as a military base - one of the key justifications for the occupation of the island ${ }^{2}-$ but were also a major impediment to its economic development. ${ }^{3}$ Faced with these challenges, the new administration undertook a range of public works over the following years. The most important of these improvements were overseen by Samuel Brown, appointed Government Engineer in 1880, whose professional achievements were listed in his obituary after his death in 1891 (see Kiely, Merrillees, this volume, Appendix 1). ${ }^{4}$

A not-unexpected result of these and other development projects was that various archaeological discoveries were made throughout the island. For example, road construction near Aradippou early in 1879 supervised by Lieutenant H.M. Sinclair of the Royal Engineers revealed some ancient tombs, as a result of which he requested permission to excavate additional burials in the area. ${ }^{5}$ Claude Delaval Cobham, the scholarly District Commissioner of Larnaka who acted as an informal agent for Charles Newton and later Alexander Murray of the British Museum from 1878 until the early $20^{\text {th }}$ century, ${ }^{6}$ preserved a funeral stele with a Phoenician inscription discovered during the construction of the highroad in the Tourabi Tekke area of Larnaka in 1881. ${ }^{7}$ Local officials also collected finds made as a result of accidental archaeological discoveries. In May 1879, Cobham took possession of a large part of a Cypro-Archaic I tomb group found at Aradippou and kept together by the local priest. ${ }^{8}$ Colonel Falkland Warren, District Commissioner of Limassol between 1878 and 1879, was almost certainly responsible for assembling the group of objects said to come from tombs around Limassol and Amathus presented to the British Museum at the same time as the finds from Larnaka-

1. S. Angelides, "The Cyprus economy under British rule", in V. Karageorghis, D. Michaelides (eds), The Development of the Cypriot Economy from the Prehistoric Period to the Present Day, Nicosia, 1996, p. 209-230, esp. p. 209-210; P. Edbury, "Cyprus in the $19^{\text {th }}$ century: Perceptions and politics", in Tatton-Brown 2001, p. 13-20, esp. p. 16-17; Hook 2009 passim; Varnava 2009, chapter 5; Morgan 2011, chapter 2; see B. Cowper, Cyprus, its past, present, and future, London, 1878, p. 22-23; S. Brown, Three months in Cyprus during the winter of 1878-9, London, 1879, p. 22-31.

2. R. Holland, D. Markides, The British and the Hellenes. Struggles for Mastery in the Eastern Mediterranean 1850-1960, Oxford, 2006, esp. p. 162-165; Varnava 2009, esp. chapters 3 and 4.

3. Varnava 2009, chapter 5; Morgan 2011, p. 6-10. Hook 2009 however takes the opposite view to Varnava and argues that Britain had a meaningful intention to make the island a British territory, though the practical realities of under-development and subsequent under-investment were the same.

4. Varnava 2009, p. 109-110, 133-143; Hook 2009, p. 141ff; also K. Schaar et al., Under the clock. Colonial Architecture and History in Cyprus, 1878-1960, Nicosia, 1995, p. 11-15.

5. Cyprus State Archives SA 03/222.

6. Merrillees 2005, p. 192-193.

7. BM ME 125096. J.L. Myres, "Excavations on Cyprus, 1894”, JHS IX, 1897, p. 152; Yon 2004, no. 1070.

8. Bailey 1969, esp. p. 40-41. 
Bamboula. ${ }^{9}$ In his account of his visit to Cyprus in April 1879, Newton reported the recent discovery of a sarcophagus containing glass objects during the construction of an aqueduct to the west of the town, as well as a tomb containing 'painted fictile vases of ordinary Cyprian pottery with geometrical pattern' in the same area. ${ }^{10}$ Some of the latter objects may number among the British Museum group. In this way, as well as through private initiatives such as sponsoring excavations (discussed by Kiely and Merrillees in this volume), numerous British officials became directly acquainted with the archaeology of the island, even if most lacked any archaeological training or indeed prior knowledge of the antiquities of the island. Nonetheless, these individuals played a major role in the development of archaeology in the early British period, including the establishment of the Cyprus Museum in 1882. ${ }^{11}$

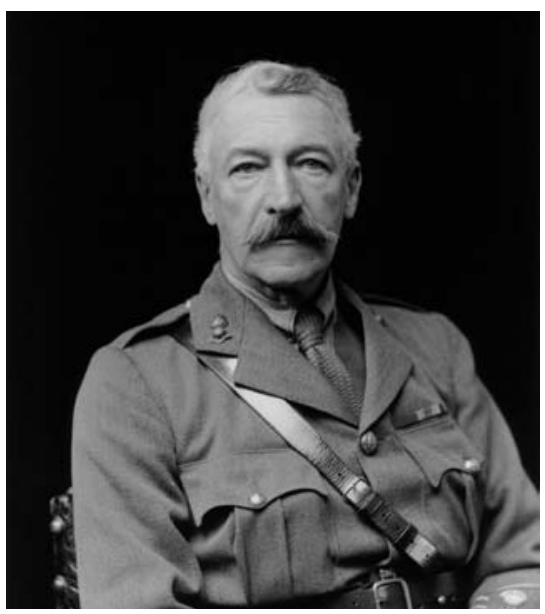

Figure 1. Hugh Montgomerie Sinclair, 1918 (By courtesy of the National Portrait Gallery).

Hugh Montgomerie Sinclair (1855-1924), who supervised the demolition at Bamboula, was a career soldier from a well-connected (if not particularly wealthy) English family (Fig. 1). ${ }^{12}$ Sinclair trained at the Royal Military Academy, Woolwich, where he was awarded a Pollock Medal for the best cadet of the year in $1874 .{ }^{13}$ He arrived on Cyprus in 1878 with the Corps of Royal Engineers, his first overseas posting. ${ }^{14}$ Several sections of his memoirs, edited posthumously by his widow Rosalie in 1926, relate to the island. His

9. Bailey 1969, p. 40.

10. Report of Newton to the Trustees on his visit to Cyprus, April 1879, BM Archives, Original Papers, 20 May 1879 (annotated transcription in Kiely 2010, Appendix 1).

11. Stanley-Price 2001, p. 270-271.

12. Sinclair 1926, esp. chapter I; Obituary in The Times, Friday, Jul 11, 1924, p. 16.

13. Anon., Memoir to Illustrate the Origin and Foundation of the Pollock Medal, London, 1875. http://www.pollock.4mg.com/Memoir.htm.

14. Sinclair 1926, chapter VIII. 
account provides an interesting, though at times unsympathetic, perspective on the island and its people during the early years of British rule. ${ }^{15} \mathrm{He}$ also mentions several public works projects with which he was directly concerned as a military engineer, though not the demolition of the Bamboula. Despite his engineering background, in 1881 Sinclair declined the offer of the position of assistant to Captain Herbert Kitchener on the Survey of Cyprus. ${ }^{16} \mathrm{He}$ instead took up the post of private secretary to the High Commissioner, Sir Robert Biddulph, a position occupied until his transfer to Ireland in 1886. There are surprisingly few references to archaeological matters in his memoirs, mainly comments on Byzantine and mediaeval monuments. He does however mention the role played by Kitchener in the establishment of the Cyprus Museum ${ }^{17}$ and how he was entrusted with its care as curator and honorary secretary after Kitchener's final departure for Egypt in 1883. Sinclair also talks about how he expanded the museum with the help of Max OhnefalschRichter. ${ }^{18}$ After further service in Britain, he saw military action in Ghana during the Fourth Ashanti war (1895-1896) and then the Boer War (1899-1902) in South Africa, between which was a period in India. Sinclair retired in 1912 with the rank of colonel but during the First World War returned to military service as Commandant of Railway Troops. He was awarded the honours of Companion of the Order of the Bath, Commander of the Order of St. Michael and St. George, and Companion of the Order of the British Empire, the latter two for his services during the Great War.

Sinclair supervised the partial demolition of the Bamboula mound in order to fill in the stagnant harbour basin of the ancient city of Kition. For centuries the marshy environment of the area around Bamboula was associated with ill-health, including malaria, especially during summer months. ${ }^{19}$ The work extended from late April until at least the first week of July in 1879 and probably for a time later. ${ }^{20}$ The archaeological

15. This includes the use of forced labour in the construction of roads (Sinclair 1926, chapter VIII passim), on which see R. Katsiaounis, Labour, Society and Politics in Cyprus during the Second Half of the Nineteenth Century, Nicosia, 1996, p. 134-135.

16. Sinclair 1926, p. 114; see R. Shirley, Kitchener's Survey of Cyprus 1878-1883, Nicosia, 2001.

17. Stanley-Price 2001, p. 270-271.

18. "We had much fortune. A vast quantity of statues, amphorae, lamps, ornaments, tear bottles, etc, came to light, and when I left we had a wonderfully interesting collection": Sinclair 1926, p. 145; see also Cyprus Museum Committee Minutes for these years. I am grateful to Dr Despina Pilides for granting access to these documents.

19. Yon 2011, p. 46; Hook 2009, p. 236. Medical knowledge had not yet ascertained that malaria was caused by mosquitoes, not stagnant air. The unhealthiness of the island, especially for military personal, was a great worry to the new authorities for political as well as medical reasons (Varnava 2009, p. 100-107).

20. Bailey 1969, p. 36-38 ; Salles 1993, p. 17-23 ; Yon 2011, p. 46-48. See report of 7 Feb. 1879 in the Cyprus State Archives, SA O3/268. The estimated cost was $£ 800$, but the stone retrieved was ear-marked for use in government buildings, and around 9 acres of reclaimed land would become government property ; see also SA 03/559 (claim by Mr Altini on ownership of the marsh); SA 1/14190-14196 (claim by Abbot of St. Joseph's convent on the stone recovered from the mound). 
damage was catastrophic, as up to a half of the original mound was destroyed. This is clearly visible in the images published by Ohnefalsch-Richter, ${ }^{21}$ though the destruction continued afterwards if we compare these images with, successively, the photograph of the Bamboula taken by Myres in $1913,{ }^{22}$ by the Swedes in 1929 (Fig. 2), and finally by the French in 1976 (Fig. 3). The disaster was compounded by the lack of proper archaeological recording of the discoveries. The minimal surviving records of the work are both inadequate by modern standards, but also difficult to reconcile either with each other or with the archaeological topography of the area as revealed by modern fieldwork (see below).

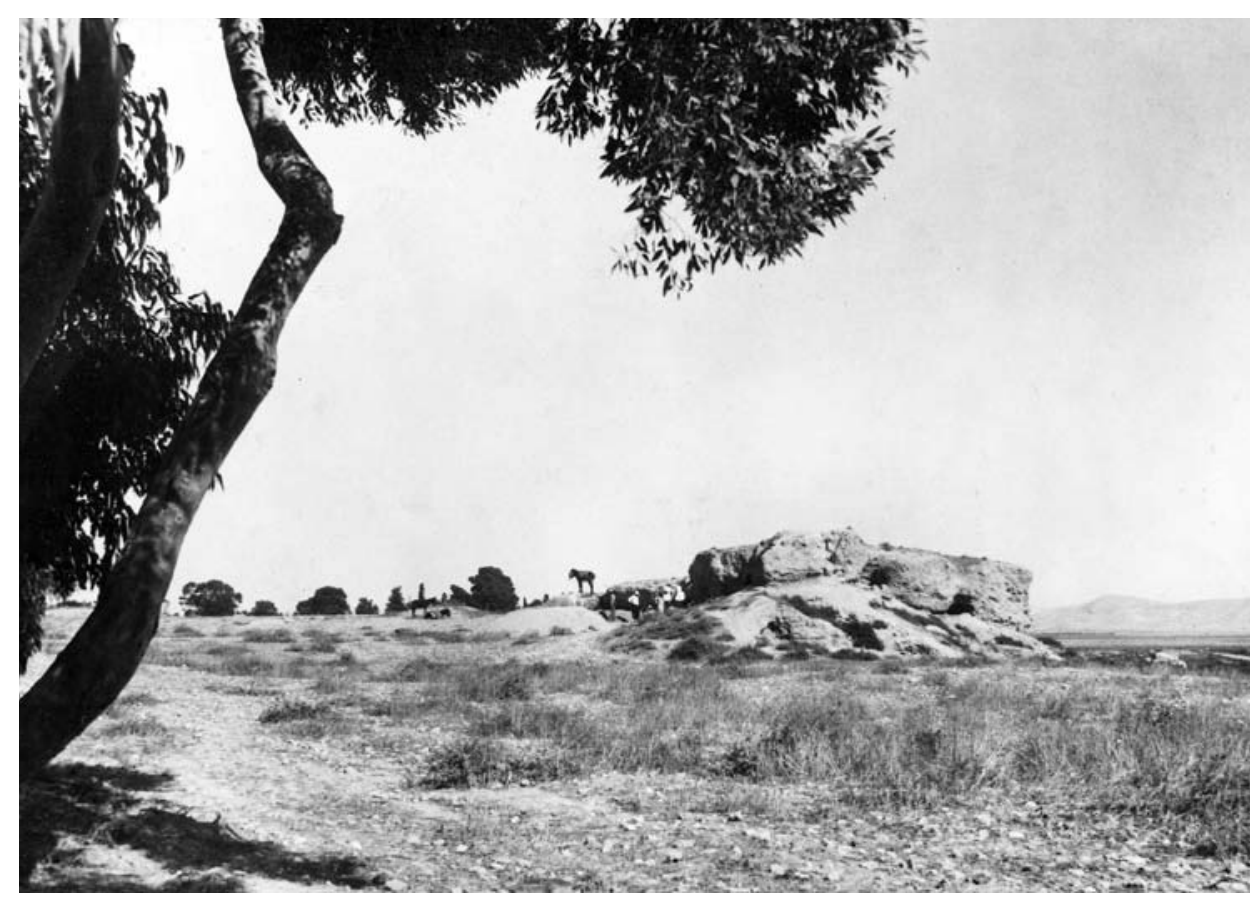

Figure 2. The hill of Bamboula, beginning of the Swedish excavations 1929 (Medelhavsmuseet, Stockholm).

Within weeks of the British occupation of 1878, Charles Newton, Keeper of Greek and Roman Antiquities at the British Museum, had lobbied the authorities to reserve all archaeological discoveries for the government - especially those on government land or resulting from engineering works (such as harbour dredging) - but also to fund organised excavations under professional supervision. ${ }^{23}$ The former happened to some degree,

21. Ohnefalsch-Richter 1893, p. 483, fig. 264-266.

22. Myres 1940-1945, pl. 30 ; Salles 1993, p. 42, fig. 14.

23. Kiely 2010 , p. 241-242. 
depending on the interests and initiative of local officials such as Cobham, Sinclair and Warren (and with the encouragement of Newton), and all private excavations were banned by the High Commissioner Sir Garnet Wolsey. Yet no arrangements were made to establish even a rudimentary archaeological service in the new territory, much less a museum in which to store casual archaeological finds. It would take four years, and an essentially private initiative (though involving numerous public officials) before the establishment of the Cyprus Museum in $1882 .^{24}$

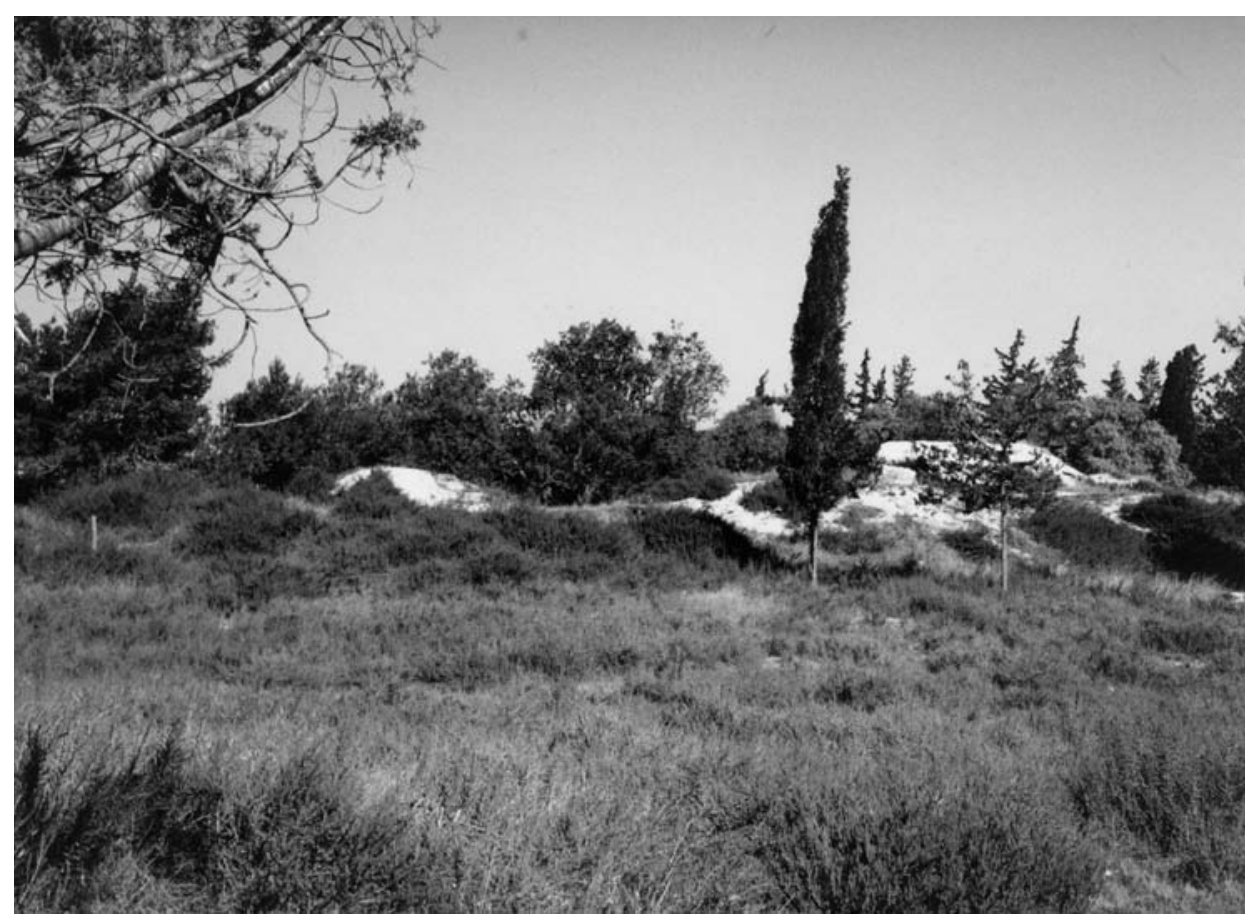

Figure 3. The hill of Bamboula, beginning of the French excavations 1976 (Mission française de Kition et Salamine).

In the absence of a local museum, some of the finds from Bamboula were sent to the British Museum in 1880, along with the material collected by Cobham and Warren mentioned above. ${ }^{25}$ They were presented in the name of the Foreign Secretary Earl Granville, but it is likely that all the items were dispatched to London at Newton's request. He visited Cyprus in May 1879 and was shown various archaeological finds

24. Stanley-Price 2001. However the early operations of the museum can in no way be described as fulfilling the role of a central (much less official) archaeological body (see Merrillees 2005; R.S. Merrillees, The First Cyprus Museum in Victoria Street, Nicosia, 2005; Kiely forthcoming).

25. Summarised in Bailey 1969, p. 39-40. 
made by local officials during his tour of the island. His report on the Aradippou tomb group explicitly states that he asked for it to be sent to the British Museum. ${ }^{26}$ The transfer must have been done with the permission of the High Commissioner - hence the formal donation in Granville's name. It is also possible that Newton recommended - either to Cobham or to Sinclair directly - that a record should be made of any discoveries at Bamboula. Sinclair's report and sketch plan of the area, initially submitted to the District Commissioner and later forwarded to the Trustees of the British Museum along with the finds from the site, is dated $7 \mathrm{July}^{27}$ [Appendix ; Fig. 4]. He states that the work had by then been in progress for ten weeks, in which case Newton almost certainly would have seen the demolition work in its early phases before leaving the island on 30 April.

Ohnefalsch-Richter's interest in archaeology was also spurred by the excavations at Bamboula ${ }^{28}$ His formal connection with the site may also be the direct result of Newton's visit of 1879 . This is not immediately clear from any of the published accounts. None of his several detailed descriptions of the area - especially the un-illustrated article in the German newspaper Das Ausland in $1879,{ }^{29}$ and a later account of 1893 in Kypros (which featured an architectural plan of the remains) $)^{30}-$ mention any formal co-operation with Sinclair. As we will see, their two respective plans differ from each other in many respects and are very difficult to reconcile, suggesting little or no mutual awareness of each other's observations. This led Salles to observe that "on serait même en droit de se demander si Sinclair et Ohnefalsch-Richter ont vu la même chose". ${ }^{31}$

Yet in his brief account of 1891, Ohnefalsch-Richter states that "I watched the removal of the hill, made photographs and measurements of the works which were being demolished, and drew for the Government a still unpublished plan". He adds that he "published in The Graphic sketches of the architecture and other finds". ${ }^{32}$ These sketches presumably refer to the engravings of the only known photographs of the site which appeared in the London periodical The Graphic in $1880 .{ }^{33}$ Some were later reused in the plates volume of Kypros, though in black-and-white and on a reduced scale. ${ }^{34} \mathrm{~A}$ previously unpublished photograph (Fig. 5) on which is based one the engravings used

26. Kiely 2010, Appendix 1, p. 247.

27. BM archives, Book of Presents, Supplementary vol. 1, 2868: see Bailey 1969, p. 36-38.

28. Ohnefalsch-Richter 1891, p. iii. Ohnefalsch-Richter worked for Newton, though indirectly via Claude Cobham, from 1880 down to 1883 (J.L. Myres, M. Ohnefalsch-Richter, Catalogue of the Cyprus Museum, Oxford, 1899, p. 1-12; see also Buchholz 1989, p. 6-8).

29. Ohnefalsch-Richter 1879; summarised in Salles 1993, p. 20-21.

30. Ohnefalsch-Richter 1893, pl. CCI and p. 482-483.

31. Salles 1993, p. 20.

32. Ohnefalsch-Richter 1891, p. 11.

33. Bailey 1969, p. 56, note 11; the colour prints are reproduced in Yon 2006, p. 24-25, fig. 10-11.

34. Ohnefalsch-Richter 1893, p. 483, fig. 263-266. 
in Kypros, ${ }^{35}$ showing a selection of the finds (including some of the items presented to the British Museum), was sent to London at some unknown point, though possibly when Ohnefalsch-Richter was already engaged by Newton as a casual excavator. The text of the article in The Graphic is anonymous (and not necessarily written by Ohnefaslch-Richter, as assumed by Buchholz, ${ }^{36}$ or by Pierides as stated by Salles ${ }^{37}$ ). The information however is attributed to the well-known Cypriot antiquarian Demetrios Pierides who, along with Cobham, is said to have introduced Ohnefalsch-Richter to Newton, presumably during the latter's 1879 visit. ${ }^{38}$ Given Newton's long-term interest in photography as a medium for recording archaeological sites,${ }^{39}$ it is possible that Ohnefalsch-Richter - who came to Cyprus in 1878 primarily as a journalist, though he also had some artistic training ${ }^{40}$ - was asked to photograph the Bamboula on account of his technical skills. For the next few years at least, from 1880 to 1883 , Ohnefalsch-Richter enjoyed the confidence of Newton, conducting a series of small-scale excavations for the British Museum, first at Kition and Salamis, and later at various sites around the island, all supervised by Cobham. ${ }^{41}$

Another uncertainty is the stage in the demolition work at which Ohnefalsch-Richter took the photographs or made his own survey of the ruins, even if he implies he was present throughout much of the work. ${ }^{42}$ Sinclair's report indicates that the work was not yet completed on 7 July, though how much longer the demolition work continued is unknown..$^{43}$ This may explain one of the most glaring inconsistencies between his plan and that of Ohnefalsch-Richter, the complete absence of the rectangular structure interpreted as a sanctuary of the "Syrian Astarte" (in 1879) or Astarte-Mikal (in 1893). This is of direct relevance to this article, as the structure is described as the findspot of the objects shown in Fig. 5.44 On face value, this provides an archaeological context for at least some of the surviving objects presented later in this paper. Here it is necessary to relate briefly

35. This is fig. 263 on p. 483.

36. Buchholz 1989, p. 6.

37. Salles 1993, p. 20 , note 21.

38. Bailey 1969, p. 56, note 11; Ohnefalsch-Richter 1891, p. iv.

39. See G. Feyler, "Contribution à l'histoire des origines de la photographie archéologique : 1839-1880", MEFRA 99/2, 1987, p. 1019-1047; R. Scott, " The Power of Photography. Charles Newton and the birth of archaeological photography ", footnote to "Digging for Glory", Cornucopia 41, 2009 [http://www.cornucopia.net/magazine/articles/ digging-for-glory].

40. Ohnefasch-Richter 1891, p. iii.

41. Ohnefalsch-Richter 1891, p. v-vi; also 1893 passim; Kiely 2010, p. 244-245. These excavations are largely unpublished but will be subject of future chapters of the Ancient Cyprus in the British Museum Online Research Catalogue.

42. Ohnefalsch-Richter 1891, p. 11.

43. He states, "[n]othing further worthy of remark has as yet come to light" (emphasis added). The text of The Graphic implies that the work was still ongoing in 1880, which seems unlikely.

44. Ohnefalsch-Richter 1893, p. 482. 
which of the features marked on the two contemporary plans of the Bamboula can be reconciled with modern discoveries in the area.

Salles' detailed analysis of the various reports is comprehensive and does not need to be repeated here in detail. ${ }^{45}$ Both contemporary accounts are very schematic and provide few insights on the archaeology of the area - certainly not without the hindsight of modern excavations. Taking Sinclair's plan first, the most important correlation with the modern archaeological record is Salles' observation that Trench $N$ on Sinclair's plan corresponds with Trench 436 of the French excavations. This major feature cuts the stratigraphy between the sanctuary area and the shipsheds of classical-period war-harbour to the north. Other features can be inferred from Sinclair's description, such as pierced stones for securing ships in the harbour basin on the north end of the area, terrace walls, various water features, and tunnels made by earlier users of the site (including antiquity hunters no doubt) are consistent with modern archaeological discoveries. Finally, Sinclair's references to artefacts are numerous but vague and provide no information on the findspots of any of the surviving objects (see Fourrier, below): masses of masonry, both cut and coarse; plain and coarse pottery throughout the area, including open lamps; the two preserved painted Phoenician inscriptions; several stone capitals near point $K$; a pile of stone balls (perhaps catapult slingshots) near point $M$; and a "copper basin beautifully oxidised with crystals inside" at point $C$ which Fourrier (below) has tentatively suggested might be the brass lamp sent to the British Museum (Cat. No. 24 below). ${ }^{46}$

As for Ohnefalsch-Richter's accounts, his first of 1879 is long but impressionistic and lacks illustrations. As Salles has noted, his detailed observation of the finds is not matched by his attention to the architectural setting. ${ }^{47}$ His few detailed descriptions of key features (especially a conical altar said to have been found in the innermost part of the shrine) are difficult to relate either to Sinclair's account and plan or to the modern archaeological map of the area. The second account from 1893 is more methodical but it is unclear when the accompanying plan was prepared. At face-value this has all the appearance of a properly-draughted architectural drawing, but the difficulty of reconciling this with Sinclair's plan or modern archaeological topography led Salles to suggest that this may have been produced at a later stage, from notes or even from memory. ${ }^{48}$

More problematic is Salles' suggested location of Ohnefalsch-Richter's sanctuary, which he places to the west of the Cypro-Archaic sanctuary area revealed first by the Swedish Cyprus Expedition in 1929 and in a much more extensive manner by the French expedition (see his figure 8). Apart from the fact that this feature is completely absent from Sinclair's plan, modern excavations in this zone have revealed the remains of workshops. These buildings may, however, have been connected to the sanctuary,

45. Salles 1993, p. 19-23.

46. Bailey 1969, p. 37-38.

47. Salles 1993, p. 20.

48. Salles 1993, p. 21. 
as in the nearby Kathari sanctuary. ${ }^{49}$ It is possible that Ohnefalsch-Richter's structure, whatever its location or function, was discovered after Sinclair's report of 7 July but also located outside the modern excavated areas. In this case, we might consider the possibility of a separate cult building or temenos, though this further undermines the accuracy of Ohnefalsch-Richter's plan which as a result is even less easy to reconcile with the scientifically-documented remains.

Finally in this regard, Fourrier's analysis of the surviving finds and those shown in Fig. 5 demonstrates that they comprise a very heterogeneous assemblage of items both in terms of date (Late Cypriot III down to Roman times) and function (religious, commercial, domestic/artisanal). They are unlike to represent the finds from a single deposit or context such as a bothros or sanctuary floor. As such, she has suggested that the nature of the preserved group is more accurately characterised by Newton's statement to the Trustees in 1880 that objects were "found in a pile of rubbish" ${ }^{50}$ This at least is how a site so thoroughly disturbed even before the demolition of 1879 , and certainty during the work, would have appeared to the inexperienced excavators of the time. OhnefalschRichter correctly understood the nature of the cult objects, presumably from his personal studies, but his sanctuary structure was probably a rationalisation of the jumbled mass of architectural features uncovered without archaeological control. Although freely admitting his archaeological inexperience at the time,${ }^{51}$ his assumptions led him to make errors in the recording of genuine features whose nature is now lost to us. Sinclair by contrast was honest in his statement that "the walls give no clue as to the design or form of the buildings but run aimlessly in all directions \& in the most perplexing manner" and attempted no reconstruction.

\section{APPENDIX: REPORT OF LIEUT. SINCLAIR}

"Mr. Newton has the honour to submit to the Trustees a letter from Lord Tenterden requesting him to inform the Trustees that Earl Granville offers to the Museum a small collection of antiquities recently discovered in Cyprus.

"This collection, which is herewith submitted, has been obtained from the following sites

"1. Near Larnaka is a mound of rubbish close to a stagnant pool of salt water which is believed to be the site of the ancient harbour of Kition. This stagnant pool, which contributed to the unhealthiness of Larnaka during the summer months, has been filled

49. I am very grateful to Sabine Fourrier for this insight.

50. Cited in Bailey 1969, p. 37.

51. "Had I known in 1879 what I now know, something would have been done in order to preserve for posterity at least adequate views and sections of the Akropolis of Kition that was cleared away. Such views and sections alas, now are lost for ever and belong to the limbo of lost hopes" (Ohnefalsch-Richter 1893, p. 483). In general he was never a competent recorder of archaeological stratigraphy, and the phasing of the shrines he excavated has to be reconstructed from the finds or from sporadic details in his text (see, for example, H.-G. Buchholz, "Tamassos-Phrangissa (1885)", CCEC 16, 1991, p. 1-15). 
up by levelling the mound of rubbish under the direction of Lieut. Sinclair R.E. whose report of these operations is enclosed herewith. Irregular foundation walls of various epochs were discovered in the mound which are shown in the tracing annexed to Lieut. Sinclair's Report.

"[Further entries on finds from Aradippou, Limassol and Amathus. The text below follows Sinclair's original punctuation for the most part with some very minor editorial additions to aid the reader].

“Lt Sinclair's Report:

"Report on Excavations at the Bamboola-Larnaca

Commissioner Larnaca

The work at Bamboola has now been carried on for about 10 weeks during which time about $£ 350$ have been spent and about 16,500 cub[ic]: yds: excavated at a cost of about $5 d$ per cubic yard. ${ }^{52}$

The depth to which the excavation has been carried is about 50 yards in the centre (from the edge towards the middle of the hill) this is only about 1/3 the distance through the hill. The average depth at this point is 30'- but it diminishes rapidly to either side.

The excavations began at A where a trench or water-course marked (-•-) was found $\&$ further on at $B$ small cemented conduits running round foundation walls; at $C$ the ruins became more important with holes filled with rubbish \& containing some rude pottery \& one copper basin beautifully oxidized with crystals inside. The ruins here are about 10 feet highthe lower part of rough masonry with very soft cement above-better masonry \& squared \& tooled stone but in such irregular positions that it has evidently been much disturbed; numerous small conduits with cemented sides \& flat stone coverings were found at various levels near this point but they could never be traced far into the buildings.

As we proceeded at $D$ a wall of very good ashlar masonry began to show itself running inwards and about 10 feet high it however stopped abruptly after about 50'-where the masonry again became rough and coarse-other rough walls in various directions were come across \& quantities of good squared stone strewn among the rubbish in astonishing confusion. No plan or design could be recognized in these amorphous masses of masonry. The earth between was generally in layers of different colour \& texture with here and there one of ashes; \& broken earthenware \& potsherds in all directions \& great quantity at E were found 2 stones with holes through them fixed in the ground \& apparently used for fastening the ships in harbour-at $F$ were found rough shafts as for wells filled up with stone and rubbish \& at $G$ a large shaft cemented inside and shaped like a retort, large at the bottom \& narrowing upwards another smaller one was near it in the middle of a rough underground passage-in which were found one or two heads and some better pottery. This passage had been explored before as on the shaft was found the date 1847 a name believed to be Van Lennep and the letters N.W.F. in Roman characters. Two other large holes are appearing at $H$ but as yet have not disclosed anything remarkable.

At $K$ was found a small arched conduit running about $10 y d s \&$ just above it the base of a pillar,- not far off were found 2 capitals of early date, one very massive the other smaller-At $L$ was found a trough of stone with a lead pipe leading to it. At M a large hole filled with roughly rounded stones as if for cannonballs (possibly for catapults.)

52. The figure of a million cubic feet is given in The Graphic (Bailey 1969, p. 56). 
$N$ is a cutting I have driven inwards in the hope of finding something; an underground hole running as shown has been found but containing nothing.

The earth is everywhere of the same nature, full of broken pottery, small stone \& mortar \& evidently the débris of former buildings. The holes running in various directions are in the earth, not in masonry \& the walls give no clue as to the design or form of the buildings but run aimlessly in all directions \& in the most perplexing manner.

The pottery is mostly of a rude nature the lamps being merely like small dishes pinched in at the corner the pottery except a few pieces of later date is unpainted and yellow-2 Phoenician inscriptions have been found written in some sort of paint on stone \& being (according to Mr. Pierides) accounts of wages. The quantity of stone brought out both squared and rough is enormous-

Nothing further worthy of remark has as yet come to light,

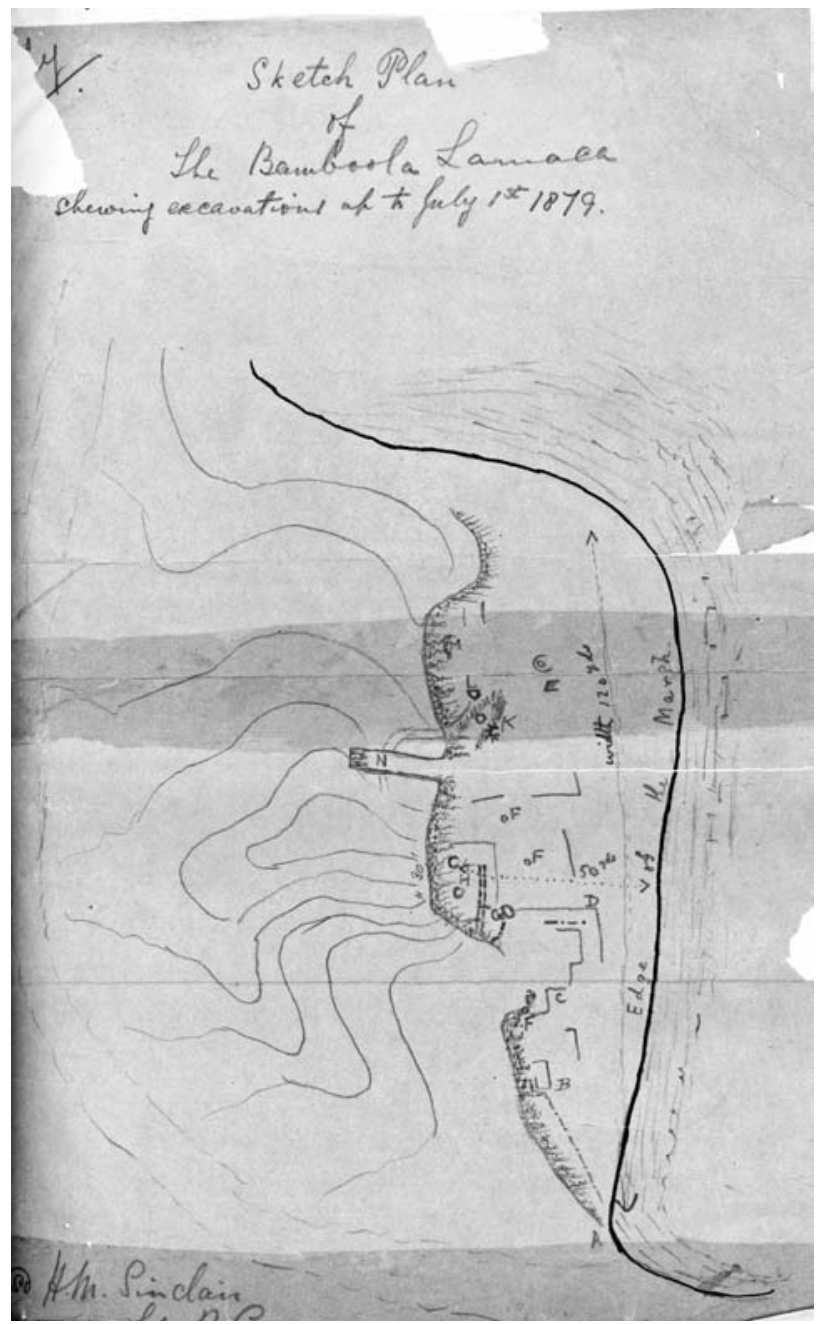

H. M. Sinclair Lt. R. E.

Larnaca 5-7-79-

Figure 4. The site of Bamboula by Lt.Sinclair 1879 (By courtesy of the Trustees of the British Museum). 


\section{LA COLLECTION D'ANTIQUITÉS DE BAMBOULA AU BRITISH MUSEUM (S.F.)}

La petite collection d'antiquités mise au jour lors des travaux britanniques de 1879 et arrivée au British Museum en 1880 par l'intermédiaire du comte Granville comporte des objets de types divers, datables du Bronze Récent à l'époque romaine. Les rapports publiés du lieutenant Sinclair et de M. Ohnefalsch-Richter ${ }^{53}$ ne permettent pas de déterminer leur contexte précis de découverte. Il n'est évidemment pas question de proposer une étude contextuelle d'un échantillon aussi réduit et dont la collecte fut pour le moins aléatoire. Mais, alors que la publication française du sanctuaire est sous presse ${ }^{54}$, il a paru intéressant de faire mieux connaître ce petit lot de trouvailles, certaines déjà bien publiées, d'autres inédites, et de le replacer dans le cadre des découvertes faites sur le site au cours des fouilles stratigraphiques des missions suédoise puis française.

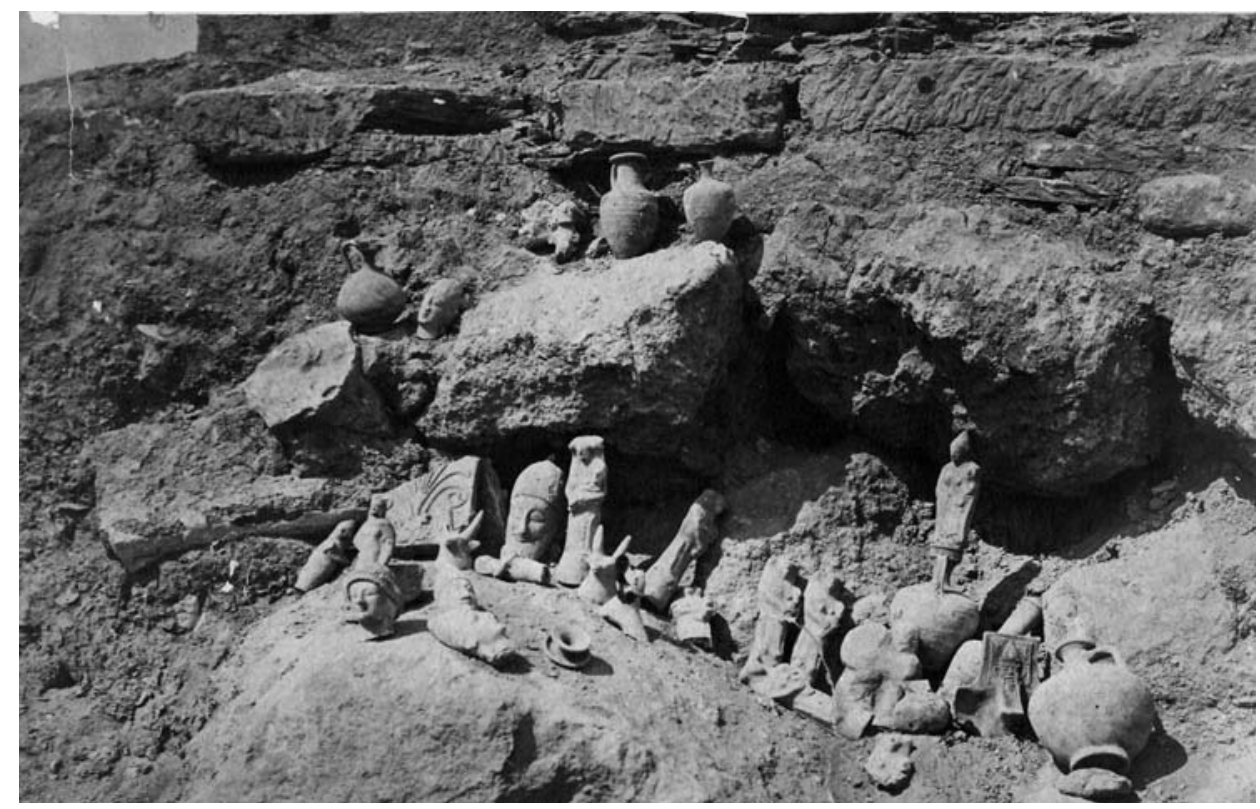

Figure 5. Photographie prise en 1879 sur le site de Bamboula

(By courtesy of the Trustees of the British Museum, archives du musée).

53. Ohnefalsch-Richter 1879 et 1893, p. 482-483.

54. $K B \mathrm{VI}$, sous presse. 
Plusieurs objets importants ont sans doute été mis au jour parmi les ruines de la Bamboula avant 1879. Il est possible que la stèle de Sargon provienne de là, même si son lieu d'érection - et de découverte - a été discuté récemment ${ }^{55}$. C'est peut-être aussi le cas des deux stèles-chapiteaux hathoriques ${ }^{56}$, mais elles ont été découvertes en remploi dans des maisons de la vieille ville ${ }^{57}$.

Si la plupart des objets figurant sur la photographie de 1879 (Fig. 5, publiée sous forme de dessin par Ohnefalsch-Richter 1893, p. 483, fig. 263) ${ }^{58}$ sont enregistrés dans les inventaires du musée, quelques-uns d'entre eux manquent à l'appel : les céramiques entières ${ }^{59}$ (cruches et amphore à anses horizontales); le vase composite complet du type cup-and-saucer qui est placé au premier plan; les autres protomes bovines qui, selon Ohnefalsch-Richter, s'ajoutaient à l'exemplaire aujourd'hui au British Museum ${ }^{60}$; ainsi que plusieurs figurines de terre cuite ${ }^{61}$. D'autres, associés au même lot dans les inventaires, ne semblent pas présents sur la photographie : ainsi la figurine de terre cuite inv. 1880/7$10 / 33$ (cat. $\mathrm{n}^{\circ}$ 4) et la dea gravida d'importation levantine inv. 1880/7-10/30 ${ }^{62}$ (cat. $\mathrm{n}^{\circ}$ 6), ou encore l'autel de calcaire inv. 1880/7-10/51 (cat. ${ }^{\circ}$ 18). Parmi les objets manquants, signalons un bassin à «palmette assyrienne » qui, selon Ohnefalsch-Richter, se dressait près de l'entrée nord-est de la pièce rectangulaire qu'il interprète comme le sanctuaire d'Astarté et Mikal ${ }^{63}$. S'agit-il du même bassin de calcaire qui apparaît au premier plan, au pied de la Bamboula, sur la photo prise par Myres en $1913^{64}$ ? Les bassins de pierre sont

55. Yon 2004, p. 344-354, $\mathrm{n}^{\circ}$ 4001. J. Smith (Art and Society in Cyprus from the Bronze Age into the Iron Age, Cambridge, 2009, p. 11) considère comme établi que la stèle était érigée dans le sanctuaire de Kathari. R. Merrillees a rassemblé, dans un article à paraître dans le RDAC 20112012, l'ensemble des archives concernant cette découverte, qui tendent à montrer que l'objet a été mis au jour dans la zone de l'église de la Phaneromeni, bien loin au sud, donc, de Bamboula. J'adresse tous mes remerciements à R. Merrillees qui m'a permis de consulter son manuscrit.

56. A. Carbillet, La figure hathorique à Chypre (II ${ }^{e} I^{e r}$ mill. av. J.-C.), AOAT 388, Münster, 2011, p. 290-291, nos A15-A16. Cf. KB VI, chap. II.5.

57. Ohnefalsch-Richter 1893, p. 481 et pl. CC.

58. Ohnefalsch-Richter 1893, p. 483, fig. 263.

59. Elles dateraient toutes, sauf une, des périodes hellénistique et romaine d'après OhnefalschRichter 1893, p. 482.

60. « Mehrere Kuhkopfidole » (Ohnefalsch-Richter 1893, p. 482).

61. Deux des deae gravidae courotrophes (quatre apparaissent sur la photographie); la figurine de courotrophe à bonnet pointu (placée à droite, derrière la cruche); ou bien encore la figurine de joueuse de tambourin de type Kamilarga, qu'on distingue, couchée devant la tête de calcaire barbue à bonnet pointu (inv. 1880/7-10/45 = cat. $\mathrm{n}^{\circ} 12$ ).

62. Cette dernière ne figure pas non plus dans le rapport de Newton présenté aux Trustees du British Museum.

63. Ohnefalsch-Richter 1893, p. 482.

64. D'après une mention de Myres (1940-1945, p. 96), ce bassin aurait été mis au jour à date plus récente, lors de la destruction d'un mur où il était remployé. 
un type de mobilier commun dans les sanctuaires chypriotes ${ }^{65}$. Plusieurs, de dimensions plus modestes, ont été mis au jour lors des fouilles françaises du sanctuaire de Bamboula. On mentionnera également une baignoire de calcaire découverte en place sur un sol du Chypro-Archaïque I ${ }^{66}$. Du sanctuaire d'Apollon à Pyla, non loin de Larnaca, provient un grand vase monolithe portant une dédicace en alphabet grec à Apollon Kéraiatès ${ }^{67}$. Enfin, les deux chapiteaux, mentionnés dans le rapport Sinclair ( 2 capitals of early date one very massive the other smaller ») sont peut-être à identifier avec les deux chapiteaux archaïques, l'un à volutes, l'autre ionique, aujourd'hui au Musée de Larnaca ${ }^{68}$.

Les trouvailles faites lors des terrassements britanniques de la colline de Bamboula, disparates et éclectiques, sont présentées ci-dessous par type de matériau et catégorie d'objet.

Les dimensions sont en centimètres.

\section{Terre cuite}

\section{Céramiques}

Parmi les vases mis au jour en $1879^{69}$, seuls cinq ( $\left.{ }^{\text {os }} 1-3\right)$ - une gourde de pèlerin d'époque romaine, trois anses rhodiennes hellénistiques timbrées et un fragment de réchaud hellénistique - sont arrivés au British Museum. L'occupation de la Bamboula à l'époque hellénistique est bien documentée ${ }^{70}$; les restes d'époque romaine semblent plus rares ${ }^{71}$, mais une grande quantité d'amphores romaines a été recueillie dans le bassin du port $^{72}$.

1. Inv. 1880/7-10/41 (Fig. 6). H. 15,9. Pâte rouge, inclusions noires et blanches. Gourde à deux anses (une cassée) de la lèvre à l'épaule ; spirale incisée sur la panse ; profil assez plat, avec maigre renflement au centre. Indicattion erronée (« Klavdia ») écrite à l'encre sur l'objet.

Le type est bien connu, par exemple à Salamine, où les gourdes ont été retrouvées dans des contextes des $\mathrm{I}^{\mathrm{er}}-\mathrm{III}^{\mathrm{e}}$ S. ap. J.-C. ${ }^{73}$.

65. Voir, pour Amathonte, A. Hermary, dans S. Fourrier, A. Hermary, Amathonte VI. Le sanctuaire d'Aphrodite des origines au début de l'époque impériale, ÉtChypr XVII, Athènes, 2006, p. 25-29.

66. A. Caubet, « Le sanctuaire chypro-archaïque de Kition-Bamboula », dans G. Roux (éd.), Temples et sanctuaires, TMO 7, Lyon, 1984, p. 111, fig. 3 ; cf. A. Caubet dans KB VI, chap. II.4.

67. Yon 2004, $\mathrm{n}^{\circ}$ 2004. Le vase est conservé au Musée de Larnaca. Pour les trouvailles de Pyla, voir O. Masson, « Kypriaka II. Recherches sur les antiquités de la région de Pyla », $B C H$ 90, 1966, p. 3-21.

68. MLA 419 et MLA 412 : Yon 2006, p. 92, fig. 53. Voir Myres 1940-1945, p. 85, à propos du chapiteau ionique, publié par Ohnefalsch-Richter 1893, pl. CXCVII,1, comme provenant de l'« acropole » de Kition.

69. Le rapport du lieutenant Sinclair mentionne de nombreux fragments de poterie, « mostly of a rude nature ». Les vases rassemblés sur la photographie de 1879 datent tous sauf un, d'après Ohnefalsch-Richter (1893, p. 482), des périodes hellénistique et romaine.

70. Salles 1993.

71. Ibid., p. 30-31.

72. Yon 2006, p. 139-141.

73. C. Diederichs, Salamine de Chypre IX. Céramiques hellénistiques, romaines et byzantines, Paris, 1980, p. $39-40, \mathrm{n}^{\text {os }} 130-133$ et pl. 12-13. 
2. Inv. 1880/7-10/38, 39 et 40 . Trois anses d'amphores hellénistiques rhodiennes imprimées

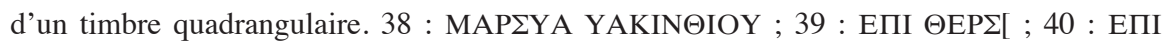

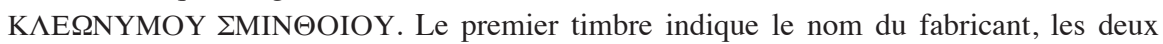
autres celui de l'éponyme, en l'occurrence à Rhodes le prêtre d'Hélios. Les noms sont accompagnés de la mention du mois.

Le fabricant Marsyas est bien attesté, sur une longue période au cours de la première moitié du II $^{\mathrm{e}} \mathrm{s}$. av. J.-C. ${ }^{74}$. On doit sans doute restituer le nom de l'éponyme Thersandros, en fonction entre 141 et 135 av. J.-C., sur le timbre inv. 1880/7-10/39 ${ }^{75}$. L'éponyme Kléônymos est également bien connu, associé à différents noms de fabricants ${ }^{76}$. Yakinthios et Sminthios sont des noms de mois rhodiens. Les timbres rhodiens sont largement prédominants parmi les anses timbrées découvertes lors des fouilles françaises de Bamboula ${ }^{77}$, comme ailleurs à Chypre dans des contextes hellénistiques.

3. Inv. 1880/7-10/36 (Fig. 7). H. cons. 14,1 ; 1. cons. 15,1. Pâte rougeâtre, avec de grosses inclusions rouges. Partie inférieure restaurée en plâtre. Fragment de réchaud hellénistique orné d'une tête barbue coiffée d'un pilos, entre deux foudres. Des parallèles proviennent des niveaux hellénistiques de Paphos ${ }^{78}$.

Publ. : Walters 1903, p. 68, A 448 (sans illustration).

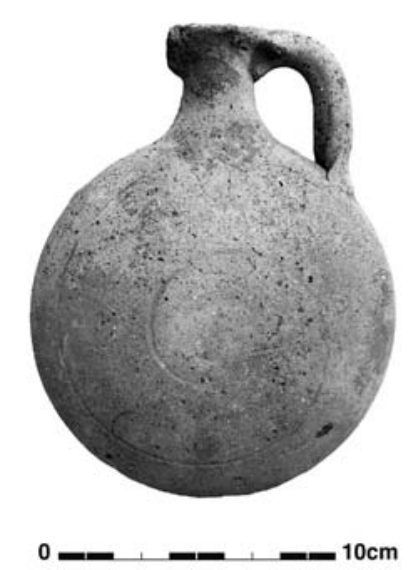

Figure 6. Cat. $1=1880 / 7-10 / 41$.

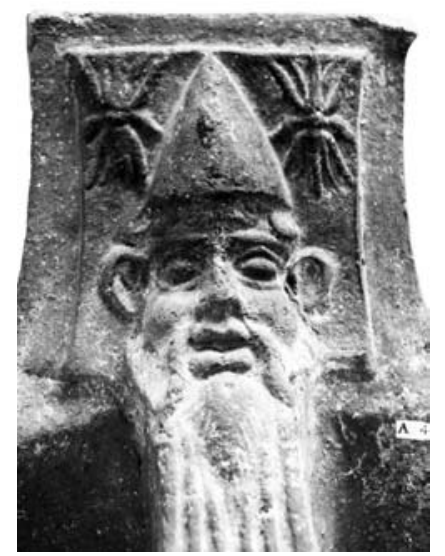

Figure 7. Cat. 3 = 1880/7-10/36 (détail).

74. Calvet 1972, p. 30, n 53 ; Y. Calvet, « Timbres amphoriques de Salamine (1971-1974) », RDAC 1978, p. 226, n 30 ; Calvet 1982, p. 28, n 68 ; Y. Calvet dans Salles 1993, p. 67, n 82 ; Y. Calvet dans Karageorghis 2005, p. 352, $n^{\circ} 32$. Une amphore portant un timbre similaire, provenant d'Ambelikou, est conservée au Cyprus Museum : Nicolaou, Empereur 1986, p. 516, nº 2.

75. Grace $1953, \mathrm{n}^{\circ} 92$; Y. Calvet dans Karageorghis 2005 , p. $347, \mathrm{n}^{\circ} 7$ et p. $352, \mathrm{n}^{\circ} 30$, avec références bibliographiques.

76. Grace 1953, n 110 ; Calvet 1972, p. 29, n 49 ; Y. Calvet dans Karageorghis 2005, p. 350, $\mathrm{n}^{\circ} 22$ et p. 355-356, n 48. L'éponyme Kléônymos est associé au fabricant Marsyas sur l'amphore d'Ambelikou au Cyprus Museum : Nicolaou, Empereur 1986, p. 516, n 2.

77. Calvet 1982.

78. J.W. Hayes, Paphos III. The Hellenistic and Roman Pottery, Nicosie, 1991, pl. XVII, 7 et pl. XVIII, 3 . 

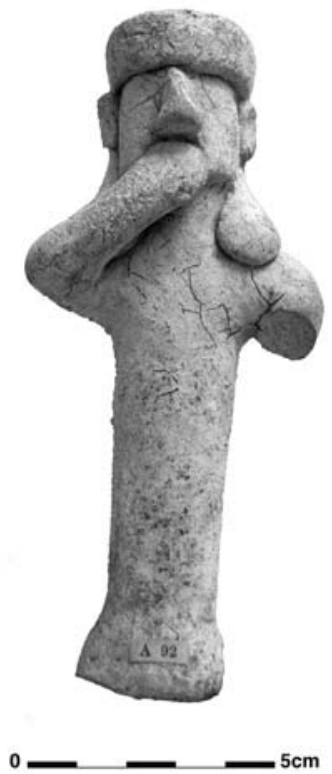

Figure 8. Cat. $4=$ 1880/7-10/33.

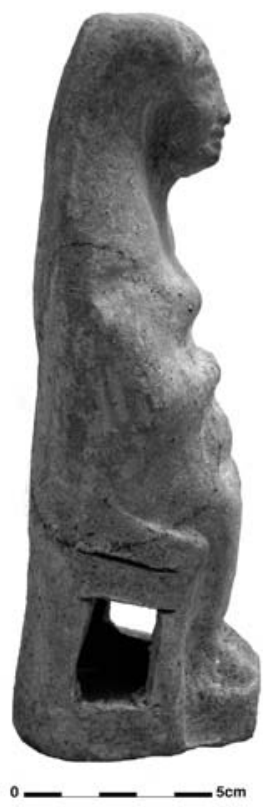

Figure 11. Cat. $6=$ 1880/7-10/30.

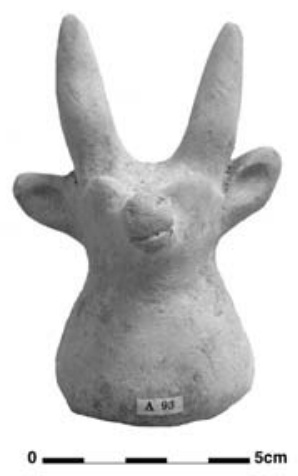

Figure 9. Cat. $5=$ 1880/7-10/35.

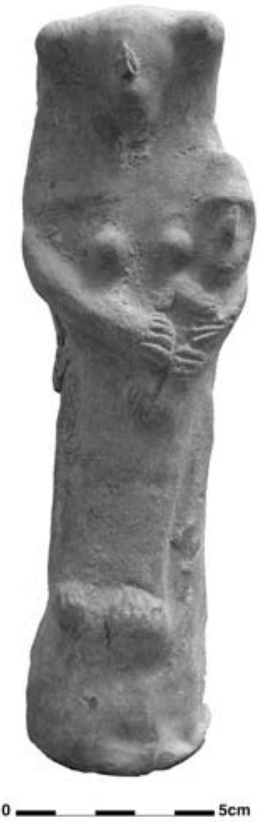

Figure 12. Cat. $7=$ 1880/7-10/31.

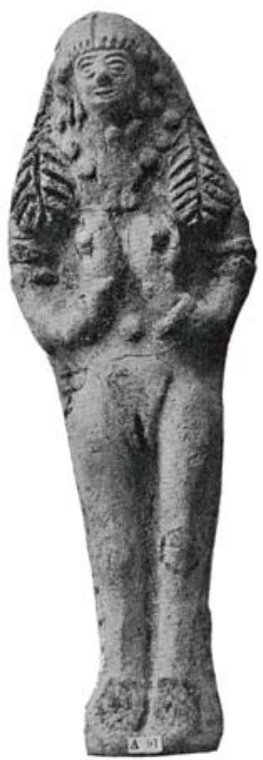

Figure 10. Figurine A $91=$ 1880/7-10/29

(d'après Walters 1903, pl. II).

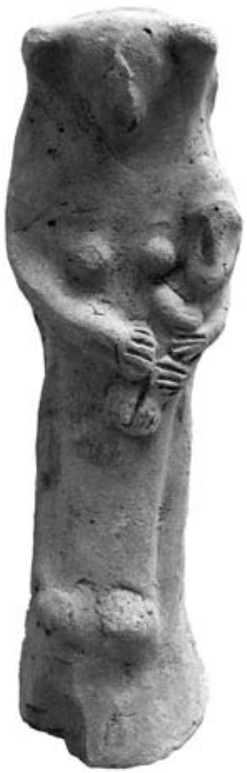

Figure 13. Cat. $8=$ 1880/7-10/32. 


\section{Figurines}

Toutes les figurines de terre cuite (entières ou presque entières) qui figurent sur la photographie prise en 1879 ne font pas partie du lot du British Museum. Le petit échantillon conservé comprend des figurines modelées en plein, moulées et fabriquées en technique mixte, qui datent de l'époque archaïque à l'époque classique ( $\mathrm{VI}^{\mathrm{e}}-\mathrm{IV}^{\mathrm{e}} \mathrm{s}$.).

\section{Figurines modelées}

Deux objets entrent dans cette catégorie : un personnage debout, une main sur la bouche, et une protome de taureau. Tous deux sont datables du Chypro-Archaïque II (VI ${ }^{\mathrm{e}}$ s. av. J.-C.).

4. Inv. 1880/7-10/33 (Fig. 8). H. 13,9. Pâte beige orangé, nombreuses inclusions noires. Surface concrétionnée, mais restes de peinture noire visibles. Figurine de terre cuite modelée en plein ; corps cylindrique plein, légèrement évasé en creux à la base (en partie cassée) ; visage au menton carré ; nez, oreilles, coiffe et bras modelés à part et rapportés. Personnage debout, le bras gauche (cassé) sans doute le long du corps, la main droite posée sur la bouche. L'objet ne semble pas faire partie des trouvailles rassemblées sur la photographie de 1879.

Publ. : Walters 1903, p. 14, A 92 (sans illustration).

La pâte comme le style indiquent que la figurine n'a pas été fabriquée à Kition ${ }^{79}$. Il est probable qu'il s'agit d'une importation d'Idalion ${ }^{80}$. Le geste (un bras le long du corps, l'autre main sur la bouche) est bien documenté, dans les productions de divers ateliers ${ }^{81}$.

5. Inv. 1880/7-10/35 (Fig. 9). H. 10,6 ; diam. base 5,8. Pâte beige orangé, petites inclusions noires. Protome de taureau modelée en plein, reposant sur une base en creux. Mufle, oreilles et cornes rapportés, yeux globuleux modelés par ajout de pâte ; détails du mufle incisés.

Publ.: Walters 1903, p. 14, A 93 (sans illustration).

Plusieurs protomes bovines auraient été retrouvées lors du démantèlement de la Bamboula en 1879, d'après le rapport d'Ohnefalsch-Richter ${ }^{82}$. Les fouilles françaises en ont pourtant seulement recueilli une, inédite, dans un contexte perturbé. Un autre exemplaire provient des fouilles chypriotes du sanctuaire de Kathari ${ }^{83}$. Ce nombre réduit contraste avec le joli lot de protomes archaïques mises au jour à Salamine, qui appartiennent toutefois à un type différent, celui des protomes à suspendre ${ }^{84}$.

79. Il existe une production kitienne de figurines modelées en plein, mais elle se distingue par un traitement très caractéristique du nez, pincé sur toute sa longueur : Fourrier 2007, p. 56 (groupe Kition-A.1).

80. Comparer, par exemple, avec les personnages qui composent le groupe du Louvre AO 22221 : Karageorghis 1995, pl. LXXVIII, 9. D'autres figurines modelées en plein d'Idalion ont été retrouvées à Kition : voir Fourrier 2007, tableau p. 154.

81. Karageorghis 1995, pl. VI, 3-4 et 6.

82. Ohnefalsch-Richter 1893, p. 482.

83. Karageorghis 2005, pl. LII, 4756.

84. T. Monloup, Salamine de Chypre XII. Les figurines de terre cuite de tradition archaïque, Paris, 1984, p. 101-102 et pl. 22. 


\section{Figurines moulées}

Toutes les figurines sont imprimées dans un moule monovalve, l'arrière étant une simple forme.

La figure de «Vénus chypriote », première dans la liste des terres cuites dressée par Newton (inv. 1880/7-10/29), est enregistrée comme manquante dans les collections depuis 1978 (Fig. 10). Je renvoie donc à la notice du catalogue de Walters ${ }^{85}$. Elle entre dans une série de production amathousienne bien connue ${ }^{86}$ et constitue donc, à Kition, une importation. On remarquera qu'elle ne semble pas être illustrée sur le florilège de trouvailles rassemblé sur la photographie de 1879.

Les trois autres figurines moulées sont des représentations du type de la dea gravida, canonique $\left(\mathrm{n}^{\circ} 6\right)$ ou superlatif (la déesse enceinte étant également courotrophe, $\mathrm{n}^{\text {os }} 7-8$ ). Le type, d'origine phénicienne et peut-être même plus spécifiquement tyrienne, a été bien étudié et il n'est pas besoin d'y revenir ici en détail ${ }^{87}$. La version « superlative », qui accumule les signes de fécondité (déesse enceinte et courotrophe), est sans doute une création kitienne, datable de la fin $\mathrm{du} \mathrm{vI}^{\mathrm{e}}$ ou du début du $\mathrm{v}^{\mathrm{e}} \mathrm{s}$. av. J.-C. Elle possède des parallèles tant parmi les trouvailles de Kathari que parmi celles de Bamboula ${ }^{88}$. Les caractéristiques techniques (notamment la base haute au-dessus de laquelle le coroplathe a tracé à la main des jambes qui se raccordent maladroitement au reste du corps) montrent que les deux courotrophes du British Museum se situent au bout d'une chaîne de surmoulages, ce que prouvent également leurs têtes petites, aux traits effacés. L'enfant, collé sous le bras de la déesse, est modelé en plein. Il est coiffé d'un bonnet pointu et ne se distingue en rien des autres figurines modelées en plein de fabrication locale. En particulier, le visage, au nez pincé sur toute sa longueur, est caractéristique du style kitien ${ }^{89}$.

La première figurine $\left(n^{\circ} 6\right)$ se distingue des autres par sa pâte et son style : il s'agit d'une importation levantine. Elle ne semble pas illustrée sur la photographie de 1879, et elle ne fait pas partie de la liste dressée par Newton pour les Trustees du British Museum. Les deux autres ( ${ }^{\text {os }} 7$ et 8 ) sont répertoriées, mais on remarquera que quatre figurines de deae gravidae courotrophes sont alignées sur la photographie de 1879, où figure également une autre courotrophe, à bonnet pointu.

85. Walters 1903, p. 13, A 91 et pl. II. H. 18,1 cm. Walters rapproche avec raison cette figurine d'un exemplaire découvert dans une tombe d'Amathonte.

86. Voir Fourrier 2007, p. 66 (groupe Amathonte-B.2).

87. Voir en particulier Yon, Caubet 1989, p. 31-32, avec références.

88. Kathari: Karageorghis 2005, pl. CIV, 4411. Bamboula: Salles 1993,p. 313 , nº 731 et fig. 258 (photographie mal orientée). Un autre exemple, provenant sans doute également de Bamboula, est aujourd'hui au Louvre : Yon, Caubet 1989, p. 43, fig. 9d.

89. Voir Fourrier 2007, p. 56 (groupe Kition-A1). 
6. Inv. 1880/7-10/30 (Fig. 11). H. 20,2. Pâte rose, petites inclusions noires, blanches et rouges. Figurine moulée en creux (l'arrière est une simple forme). La déesse repose sur un trône dont le dessous a été évidé.

7. Inv. 1880/7-10/31 (Fig. 12). H. 19,1. Pâte beige, fine, petites inclusions noires. Figurine moulée en plein, seule la base est creuse pour permettre la stabilité de l'objet. Arrière lissé. Enfant modelé. Nombreuses retouches par incisions (mains, bras et jambes).

8. Inv. 1880/7-10/32 (Fig. 13). Fig. 13. H. 18,8. Pâte beige, fine, inclusions noires et rouges. Même type que le précédent. Les traits du visage de la déesse sont encore plus émoussés, trahissant de nombreux surmoulages.

\section{Figurines réalisées en technique mixte}

La collection du British Museum ne comprend aucune figurine du type de Kamilarga, pourtant si fréquent parmi les terres cuites découvertes à Kition ${ }^{90}$. Il est toutefois possible d'en distinguer au moins une, placée à gauche de l'antéfixe sur la photographie de 1879. La figurine du British Museum est un fragment de cavalier, au corps modelé et au visage imprimé dans un moule. Le type est bien connu parmi les découvertes du sanctuaire d'Apollon Hylatès à Kourion, où il est décliné en de nombreuses variantes, sur plusieurs générations de moules ${ }^{91}$. Il semble moins fréquent à Kition, où quelques parallèles ont toutefois été recueillis dans les niveaux récents de Kathari ${ }^{92}$. On notera d'ailleurs que notre exemple porte, comme d'autres de Kathari, une coiffe particulière, que V. Karageorghis propose d'interpréter comme une tiare ${ }^{93}$. L'objet doit dater de la période fin $\mathrm{V}^{\mathrm{e}}$-début $\mathrm{IV}^{\mathrm{e}} \mathrm{S}$. av. J.-C.

9. Inv. 1880/7-10/34 (Fig. 14). H. cons. 10,3. Pâte beige orangé, fine, petites inclusions noires.

Corps et coiffe (en partie cassés) modelés, visage imprimé dans un moule. Les oreilles sont arrachées. Seul le torse, avec le départ des bras tendus vers l'avant, est conservé.

Publ. : Walters 1903, p. 60, A 396 (sans illustration).

\section{Autres}

Les autres objets de terre cuite mis au jour en 1879 sur la Bamboula et aujourd'hui au British Museum sont un peson et une antéfixe ${ }^{94}$.

10. Inv. 1880/7-10/42 (Fig. 15). Diam. 8 ; ép. 2,2 ; poids 173 gr. Pâte rouge, serrée, petites inclusions noires. Peson circulaire, deux trous de suspension. L'objet est inscrit avec le $\mathrm{n}^{\circ}$ erroné 52 .

Il est impossible de dater précisément cet objet, d'un type très courant ${ }^{95}$.

90. Yon, Caubet 1989, p. 29-31.

91. J.H. Young, S.H. Young, Terracotta Figurines from Kourion in Cyprus, Philadelphie, 1955.

92. Karageorghis 2005, pl. XC, 4127 et pl. CI, 1440.

93. V. Karageorghis, « À propos de Kitiens portant la tiare », Semitica 39 (Hommage à Maurice Sznycer II), 1990, p. 1-5, pl. I.

94. Je remercie vivement M.-F. Billot pour ses commentaires et les indications bibliographiques concernant cet objet.

95. Voir, par exemple, J.-F. Salles, M.-J. Chavane, dans Salles 1993, p. 339, nº 846 et fig. 264. 


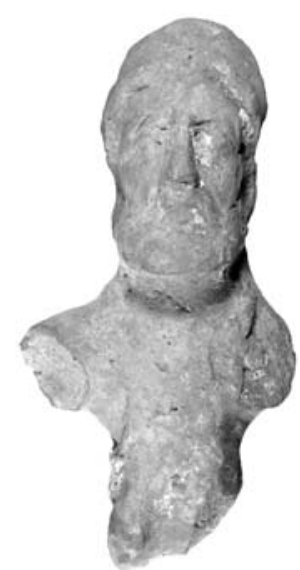

Figure 14. Cat. $9=$ $1880 / 7-10 / 34$.

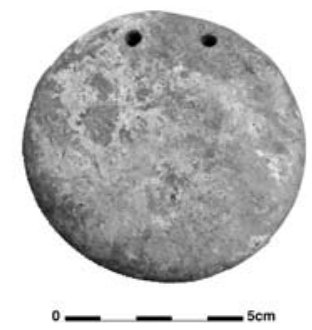

Figure 15. Cat. $10=$ 1880/7-10/42.

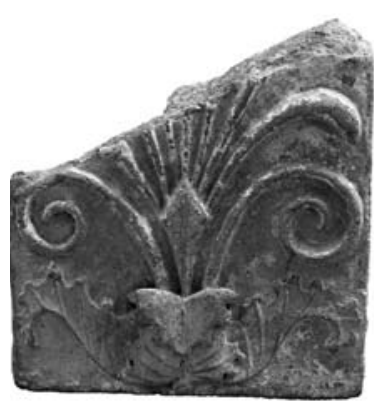

$0-$ - sen $^{\text {sen }}$

Figure 16. Cat. $11=$ $1880 / 7-10 / 37$.

11. Inv. 1880/7-10/37. Fig. 16. H. cons. 16,5 ; 1. 15,4 ; ép. max. 5,3. Pâte marron, inclusions noires et rouges. Partie supérieure cassée. Fragment d'antéfixe ornée d'un culot d'acanthe et d'une palmette avec deux tiges enroulées en volutes.

Publ. : Walters 1903, p. 69, A 450 (sans illustration).

Les rapprochements stylistiques que l'on peut faire avec d'autres décors architecturaux, de terre cuite et de marbre, orientent vers une datation entre 340 et 260 av. J.-C. environ ${ }^{96}$. La palmette évoque également, sous une forme simplifiée, le motif végétal qui orne des stèles funéraires en marbre d'époque classique ${ }^{97}$. Reste à se demander à quel bâtiment, de la fin de l'époque classique ou du début de l'époque hellénistique, cette antéfixe pouvait appartenir. Deux grands bâtiments sont attestés dans le secteur de Bamboula dans la deuxième moitié du IV ${ }^{\mathrm{e}} \mathrm{s}$. av. J.-C. : le Bâtiment sud et les néoria du port de guerre. Tous deux peuvent avoir eu un toit avec un décor de bordure ${ }^{98}$.

\section{Calcaire}

Quatre têtes masculines appartenant à des statuettes de calcaire font partie de la collection de Bamboula au British Museum. Les fouilles suédoises ont mis au jour en 1929 un bothros de sculptures en calcaire, datant pour l'essentiel de la fin de l'époque

96. Antéfixe de terre cuite trouvée à l'Asclépieion de Paros : A. Ohnesorg, Inselionische Marmordächer, Berlin-New York, 1993, pl. 51, 1-2. Décors de marbre : F. Rumscheid, Untersuchungen zur kleinasiatischen Bauornamentik des Hellenismus, Mayence, 1994, pl. 150, 4-5 (Priène, temple d'Athéna Polias).

97. Par exemple la stèle MLA 1103, découverte dans la nécropole de Kition-Agios Georgios : Yon 2004, n $1132=$ Pogiatzi 2003, n 76. D'autres couronnements de stèles, datés du IV s. av. J.-C., sont assez proches : Pogiatzi 2003, $\mathrm{n}^{\text {os }}$ 77-78.

98. Il est même possible que le toit du Bâtiment sud ait été, au moins partiellement, refait au début de l'époque hellénistique (voir O. Callot, dans Salles 1993, p. 152-143). On peut donc lui attribuer une antéfixe datée de la première moitié du $\mathrm{III}^{\mathrm{e}} \mathrm{s}$. av. J.-C. 
archaïque et de l'époque classique et parmi lesquelles prédomine le type du dieu imberbe combattant dit «Héraklès-Milqart » ${ }^{99}$. Certaines têtes du British Museum sont plus anciennes. Très peu de sculptures en calcaire ont été recueillies lors des fouilles françaises de Bamboula ${ }^{100}$; elles sont également rares dans le sanctuaire de Kathari.

12. Inv. 1880/7-10/45. Fig. 17. H. cons. 19 ; ép. 8,6. Tête barbue portant un bonnet à pans relevés. Visage allongé, grands yeux en amandes. Première moitié du vi ${ }^{\mathrm{e}}$ s. av. J.-C. ${ }^{101}$.

Publ. : Pryce 1931, p. 36, C 69.

13. Inv. 1880/7-10/47. Fig. 18. H. cons. 11,2 ; ép. 6,5. Restes de peinture rouge sur les lèvres.

Tête imberbe coiffée d'un bonnet pointu. Vers le milieu du vI $\mathrm{e}$. av. J.-C.

Publ.: Pryce 1931, p. 34, C 58 (sans illustration).

14. Inv. 1880/7-10/46. Fig. 19. H. cons. 11,2 ; ép. 5 . Restes de peinture rouge sur le bonnet et les lèvres. Tête imberbe coiffée d'un bonnet à pans relevés. Vers le milieu du vi ${ }^{\mathrm{e}} \mathrm{s}$. av. J.-C.

La tête est proche d'un exemple mis au jour par les Suédois à Bamboula ${ }^{102}$ et d'une autre tête, découverte à Kathari ${ }^{103}$.

Publ. : Pryce 1931, p. 33, C 57 (sans illustration).

15. Inv. 1880/7-10/48. Fig. 20. H. cons. 10,4 ; ép. 7,8. Restes de peinture rouge sur les lèvres, de noir sur les cheveux et les yeux. Tête de jeune homme imberbe à cheveux courts. Les cheveux sont piquetés en léger relief sur le crâne, ils retombent en mèches tubulaires, plus longues à l'arrière que sur le front. Premier quart du v $v^{e} s$. av. J.-C. Une statuette de style voisin, à couronne de feuillage, a été découverte par les Suédois ${ }^{104}$.

Publ. : Pryce 1931, p. 44, C 87 et fig. p. 43.

La sculpture de sphinx inachevée est particulièrement intéressante, car elle révèle l'existence d'ateliers à Bamboula. Aucune trace n'en a été repérée lors des fouilles suédoises et françaises. Ces dernières ont toutefois mis en évidence un quartier artisanal, qui fonctionnait à l'époque archaïque, immédiatement à l'ouest de la cour du sanctuaire. D'après les aménagements, outils et déchets retrouvés, on y pratiquait un artisanat textile et métallurgique. Du sanctuaire de Kathari proviennent des fragments d'ivoire brut, qui témoignent de la pratique d'autres activités artisanales ${ }^{105}$.

16. Inv. 1880/7-10/49. Fig. 21. H. 15,2 ; 1. 11,5; ép. 4,9. Sphinx assis, la tête tournée vers la droite. Le revers, très plat, suggère que l'objet était destiné à être appuyé contre un mur (la forme de la base rend toutefois peu probable qu'il s'agisse d'un couronnement de stèle funéraire).

Publ. : Pryce 1931, p. 143, C 433.

99. Gjerstad et al. 1937, p. 54-61.

100. M. Yon dans $K B$ VI, ch. II.5.

101. Comparer avec certaines têtes de Golgoi au Louvre : Hermary 1989, p. 26-27, ${ }^{\text {os }} 7-11$.

102. Gjerstad et al. 1937, pl. V, n 561 (« Style IA »).

103. Karageorghis 2005, pl. LXIV, 787 (provenant du Bothros 1, Floor 2).

104. Gjerstad et al. 1937, pl. XIX, $541+278$ (« style IIIA »).

105. Karageorghis 2005, p. 90 et 103, pl. XXXI, 891 ; pl. XLIII, 1751. 


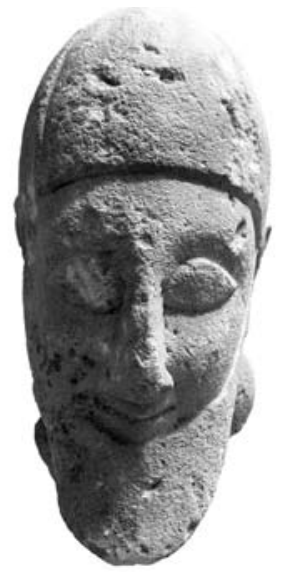

Figure 17. Cat. $12=$ 1880/7-10/45.

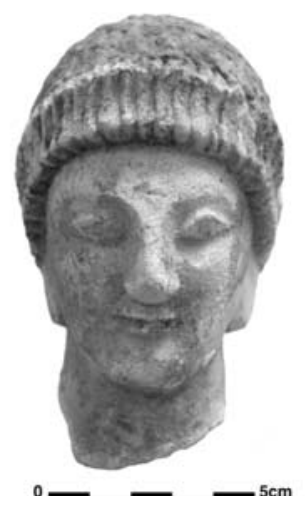

Figure 20. Cat. $15=$ 1880/7-10/48.

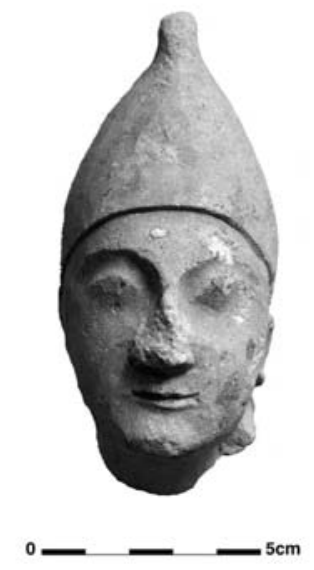

Figure 18. Cat. $13=$ 1880/7-10/47.

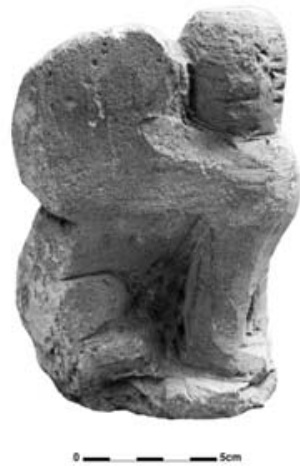

Figure 21. Cat. $16=$ 1880/7-10/49.

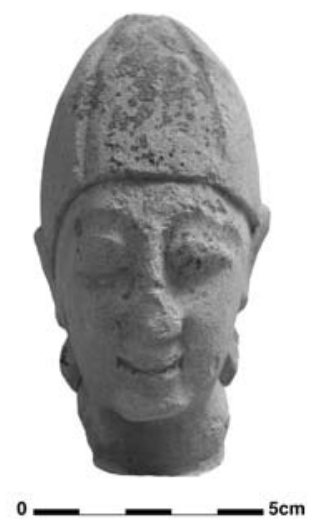

Figure 19. Cat. $14=$ 1880/7-10/46.

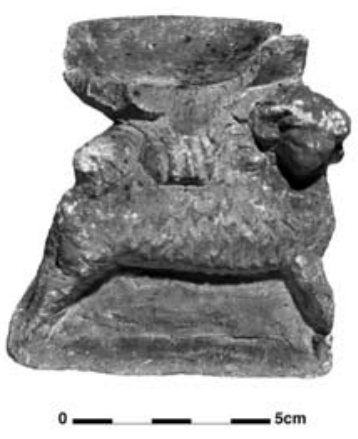

Figure 22. Cat. $17=$ 1880/7-10/50.

Les statuettes de sphinx appartiennent généralement à des brûle-parfums, la vasque étant soutenue par la tête et/ou les ailes de l'animal fantastique ${ }^{106}$. Ce n'est pas le cas de notre exemple. Les statuettes libres de sphinx sont rares : deux beaux exemples funéraires de Marion sont conservés au Musée du Louvre ${ }^{107}$; deux sphinx couchés, coiffés de la double couronne égyptienne et formant un groupe avec quatre lions, ont été découverts

106. Karageorghis 1988. De très nombreux exemplaires ont été mis au jour à Amathonte : A. Hermary, Amathonte V. Les figurines en terre cuite archä̈ques et classiques. Les sculptures en pierre, ÉtChypr XV, Athènes, 2000, p. 134-140, n ${ }^{\text {os }} 882-836$.

107. Hermary 1989 , p. $467, \mathrm{n}^{\text {os }} 970-971$. 
récemment dans la zone des tombes royales de Tamassos ${ }^{108}$. Un sphinx fragmentaire en marbre de belle facture provient du dépôt de la « rampe des Perses » de Palaepaphos et ne doit donc pas être funéraire ${ }^{109}$. Tous ces exemples sont toutefois d'une qualité bien supérieure à celle du sphinx inachevé de Bamboula, qu'on rapprochera plutôt de deux petits sphinx archaïques de Salamine ${ }^{110}$.

Le brûle-parfum à support de bélier entre dans une série bien connue.

17. Inv. 1880/7-10/50 (Fig. 22). H. cons. 9,9 ; diam. de la vasque 8,9 environ. Brûle-parfum en calcaire, composé d'une base ovoïde et d'une vasque circulaire peu profonde reposant à l'arrière sur un support cylindrique, à l'avant sur un groupe sculpté très plat comprenant un bélier debout à gauche surmonté d'une tête barbue. Vasque et tête en partie cassées. Restes de peinture jaune et rouge. Première moitié du v $\mathrm{e}$ s. av. J.-C.

Publ. : Pryce 1931, p. 144-145, C 441 ; Karageorghis 1988, p. 90, n 6 (mention) ; H.G. Buchholz, « Der Gott Hammon und Zeus Ammon auf Zypern », AM 106, 1991, p. 124, $n^{\circ} 64$.

On ne reviendra pas ici sur l'identification de la divinité, sans doute un Zeus Ammon assimilé dans le panthéon chypriote ${ }^{111}$, ni sur le rôle des ateliers de Salamine, d'Idalion et de Kition dans la création et la diffusion de ce type, bien attesté dans l'ensemble de la Messorée. La prédominance des thymiateria de ce type dans la région d'Idalion - Golgoi (dont deux exemples très proches de notre objet découverts respectivement à GolgoiAgios Photios et à Golgoi-Malloura) invite à suggérer que le type a été créé dans les prolifiques ateliers de sculpteurs de la région ${ }^{112}$. Comme l'a bien montré D.B. Counts, le type du dieu au bélier est, comme celui du dieu au lion, une image divine largement diffusée dans les sanctuaires des régions de Salamine, Kition et Idalion ${ }^{113}$. Les liens iconographiques étroits qu'on peut repérer dans l'iconographie divine des royaumes d'Idalion et de Kition, dès la période tardo-archaïque et davantage encore à l'époque classique, ne sont sans doute pas étrangers à leurs liens politiques (de concurrence et d'antagonisme d'abord, de soumission ensuite). Aucun brûle-parfum n'a été découvert lors des fouilles récentes de Bamboula. Plus qu'au hasard, je pense que cette absence est liée au type d'objet utilisé dans le sanctuaire phénicien pour faire brûler des substances aromatiques. Les fouilles françaises ont, en effet, recueilli plusieurs bassins de calcaire et de terre cuite portant des traces de feu sur la face interne et, surtout, une grande quantité de vases composites de terre cuite du type couramment appelé cup-and-saucer dans la

108. En dernier lieu Buchholz 2010, p. 545-562. Sur les sphinx funéraires, ibid., p. 562-580.

109. Ibid., p. 570-571, n 1 .

110. Cf. M. Yon, « Les lions archaïques », dans J. Pouilloux (dir.), Salamine de Chypre IV, Anthologie salaminienne, Paris, 1873, p. 30, pl. 10 c, f. Je remercie M. Yon de ses indications.

111. A. Hermary, « Représentations de Zeus-Ammon à Chypre : à propos d'un article récent », CCEC 18, 1992, p. 15-20, pl. I-V ; Counts 2009.

112. Counts 2009, p. 109, fig. 11.11 et 11.12 .

113. D.B. Counts, « Master of the Lion: Representation and Hybridity in Cypriote Sanctuaries », AJA 112, 2008, p. 3-27 et Counts 2009. 
littérature archéologique du Levant sud ${ }^{114}$. C'est cette dernière forme qui représente le brûle-parfum caractéristique du sanctuaire au cours des périodes archaïque et classique. On remarquera d'ailleurs qu'un cup-and-saucer complet figure au premier plan de la photographie prise en 1879 .

L'autel portatif devait avoir un usage voisin ${ }^{115}$.

18. Inv. 1880/7-10/51 (Fig. 23). H. 7,8 ; L 6,9 ; 1. 5,9. Autel rectangulaire en calcaire, une moulure à la base, deux au sommet, partie supérieure en cuvette. Restes de peinture bleue et rouge conservés au niveau des moulures. Cassé sur un côté. III ${ }^{\mathrm{e}}-\mathrm{II}^{\mathrm{e}}$ s. av. J.-C. ?

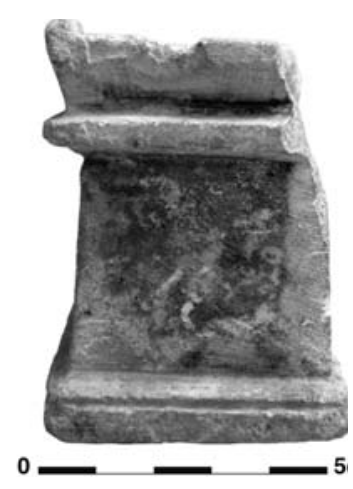

Figure 23. Cat. $18=$ $1880 / 7-10 / 51$.
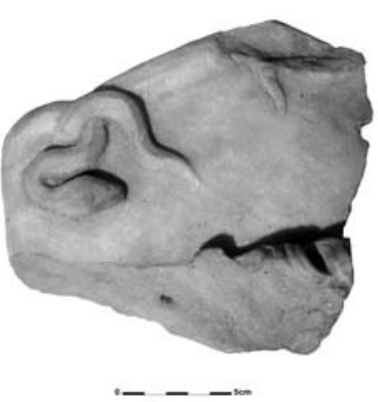

Figure 24. Cat. $19=$ $1880 / 7-10 / 25$.

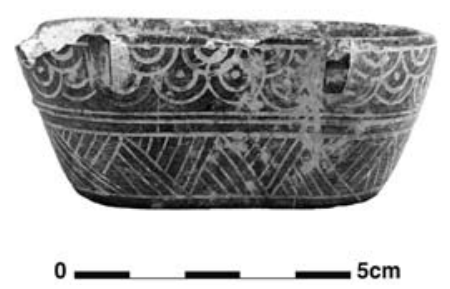

Figure 25. Cat. $20=$ $1880 / 7-10 / 52$.

Les fouilles suédoises et françaises de Bamboula ont mis au jour de nombreux autels, de types divers, depuis les niveaux du Chypro-Géométrique III (IX ${ }^{\mathrm{e}}$ s. av. J.-C.) jusqu'à ceux de la fin de la période classique (fin du $\mathrm{IV}^{\mathrm{e}} \mathrm{s}$. av. J.-C.). Ces autels entrent dans deux catégories principales, souvent associées dans un même aménagement cultuel : les autels bas (foyers, plates-formes ou simples blocs posés à plat sur le sol), et les autels hauts, catégorie à laquelle on peut rattacher l'exemple miniature du British Museum ${ }^{116}$. Il peut s'agir, là encore, de simples blocs fichés verticalement dans le sol, ou de petits monuments plus élaborés. Ainsi, le premier autel géométrique est un bloc de grès évidé en cuvette dans sa partie supérieure, très semblable à des autels du Bronze Récent (par exemple ceux du sanctuaire du Dieu au Lingot d'Enkomi). Celui du Iv ${ }^{\mathrm{e}}$ siècle est un beau

114. Cf. A. Caubet dans $K B$ VI, ch. II.3.

115. C.G. Yavis, Greek Altars, Saint Louis, 1949, p. 171-175. Pour les petits autels «brûleparfum » de Salamine, de forme sensiblement différente, voir M.-J. Chavane, Salamine de Chypre VI. Les petits objets, Paris, 1975, p. 119-124.

116. Pour les autels de Chypre, et notamment de Kition, voir M. Yon, E. Raptou, « Autels de Chypre », dans R. Étienne, M.-T. Le Dinahet (éd.), L'espace sacrificiel dans les civilisations méditerranéennes de l'antiquité, Paris et Lyon, 1991, p. 167-173. 
bloc quadrangulaire de calcaire de $1 \mathrm{~m}$ de haut, orné de deux moulures ${ }^{117}$. La découverte d'un petit autel de date probablement hellénistique à Bamboula fournit une information intéressante concernant la pratique de cultes dans la zone à cette époque.

\section{Marbre}

Deux fragments de sculptures en marbre auraient été trouvés en 1879 sur la Bamboula. C'est d'autant plus remarquable que le marbre, forcément importé, est rarement utilisé dans la sculpture chypriote ${ }^{118}$. La tête féminine (inv. 1880/7-10/24) mentionnée dans la liste de Newton n'a pas été retrouvée dans les collections du musée. Le second fragment est peut-être un élément d'applique.

19. Inv. 1880/7-10/25. Fig. 24. L. max. 15,$5 ; 1.15$; ép. de 2 à 7,9. Élément d'applique (?) en marbre, portant la représentation de deux serpents en relief (seul le bout de la queue du second est visible), bourrelet orné de mèches en léger relief. L'objet est complet sur deux côtés, fragmentaire sur les deux autres où se trouvent des trous de fixation.

Newton proposait d'interpréter l'objet comme un fragment de bassin. On peut aussi penser à un élément d'applique : une égide ${ }^{119}$ ?

\section{Autres pierres}

Les autres objets en pierre comprennent un modèle de baignoire en stéatite (?) et trois objets en albâtre (gypse local).

20. Inv. 1880/7-10/52 (Fig. 25). H. 3,5 ; L 9,1 ; 1. 4,9. Baignoire miniature en pierre sombre locale (stéatite ?), munie de quatre petites anses verticales. Décor gravé sur la paroi extérieure : triangles hachurés dans la partie inférieure, écailles dans le haut. Chypriote Récent IIIA.

Les baignoires, en calcaire et en terre cuite, font leur apparition à Chypre au $\mathrm{XII}^{\mathrm{e}} \mathrm{s}$. av. J.-C. et continuent d'être attestées au début du Chypro-Géométrique I, en particulier dans les nécropoles de Palaepaphos ${ }^{120}$. Les modèles miniatures en pierre ne sont connus qu'au Chypriote Récent III ${ }^{121}$. L'association des deux motifs décoratifs (hachures

117. Il a été découvert par les Suédois : Gjerstad et al. 1937, p. 7, fig. 10 (autel 38). Resté in situ, il a été retrouvé par la mission française en 1978, mais seule la partie inférieure était conservée (H. cons. actuelle $62 \mathrm{~cm}$ ). Sur ces deux autels, voir A. Caubet dans $K B$ VI, ch. II.4.

118. Voir le bilan présenté par A. Hermary, « La sculpture en marbre à Chypre à l'époque hellénistique et sous l'Empire. Essai de bilan », CCEC 39, 2009, p. 153-176, en particulier p. 157159 pour Kition.

119. On ne possède qu'une mention épigraphique d'Athéna à Kition : Yon 2004, n 2003.

120. E. Raptou, « Nouveaux témoignages sur Palaepaphos à l'époque géométrique d'après les fouilles de Kouklia-Plakes », CCEC 32 (Hommage à Marguerite Yon), 2002, en particulier références p. 119 , note 12 .

121. L. Åström, P. Åström, The Swedish Cyprus Expedition IV/1D. The Late Cypriote Bronze Age. Other Arts and Crafts, Lund, 1972, p. 544, fig. 71:43 ; V. Karageorghis et al., The Cyprus Collections in the Medelhavsmuseet, Nicosie, 2003, p. 111-112, n 121 (d'Enkomi) ; D. Collard, Function and Ethnicity: Bathtubs from Late Bronze Age Cyprus, SIMA Pocket-Book 171, Sävedalen, 2008, surtout p. 148-150. L'exemplaire de Bamboula n'apparaît pas dans ce catalogue, qu'il faut également compléter avec deux autres objets conservés au British Museum : une baignoire miniature en stéatite de Kourion, qui provient probablement d'une tombe (fouilles de 
et écailles) se retrouve sur des vases de pierre tendre de fabrication chypriote ${ }^{122}$. Les modèles de baignoires sont un mobilier généralement funéraire : si notre objet provient bien de Bamboula, il indique la présence de tombes du Bronze Récent dans la zone. Or, les fouilles françaises ont justement mis au jour, dans un sondage très limité au nord de la colline, un abondant matériel qui provient selon toute vraisemblance d'une ou plusieurs tombes pillées du Bronze Récent ${ }^{123}$. Les vases d'albâtre local (en réalité du gypse, une pierre très abondante dans la région de Larnaca) ${ }^{124}$ appartiennent, eux, au premier millénaire, même si leur datation précise est difficile.

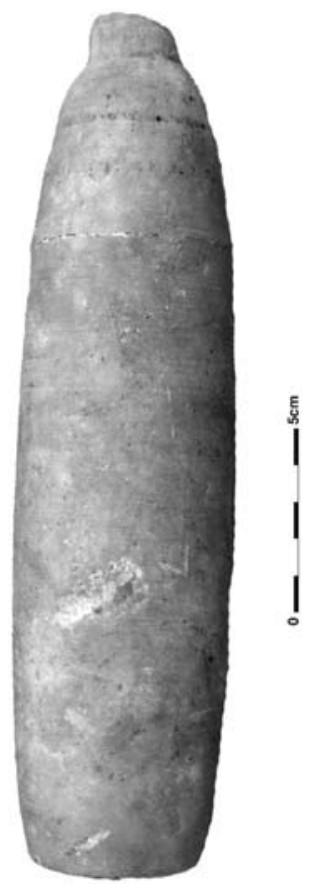

Figure 26. Cat. $21=$ $1880 / 7-10 / 26$.

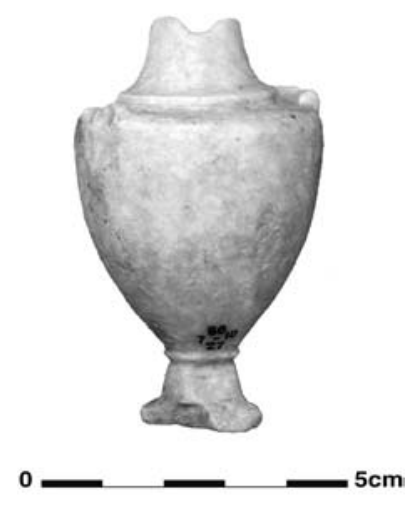

Figure 27. Cat. $22=$ $1880 / 7-10 / 27$.
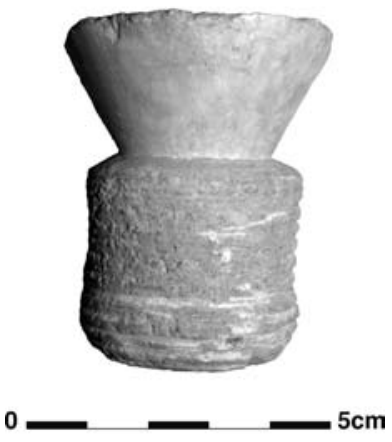

Figure 28. Cat. $23=$ $1880 / 7-10 / 28$.

Hake-Kitchener, 1882, inv. GR 2010,5001.1), et une autre en terre cuite, découverte dans la T. 102 d'Épiskopi-Bamboula lors des fouilles du British Museum de 1895 (inv. GR 1896,2-1.63 ; voir A.S. Murray, A.H. Smith, H.B. Walters, Excavations in Cyprus, Londres, 1900, p. 81, Tomb 102, $\mathrm{n}^{\circ}$ 9, sans illustration; l'objet est identifié comme une représentation de panier par Walters 1903, p. 64, A 421). Voir le catalogue en ligne rédigé par T. Kiely («Kourion », Ancient Cyprus in the British Museum, http://www.britishmuseum.org/research). Je dois ces références à Thomas Kiely, que je remercie vivement.

122. Comparer, par exemple, avec A. Caubet, A. Hermary, V. Karageorghis, Art antique de Chypre au Musée du Louvre, Athènes, 1992, p. 54, nº 43.

123. Yon, Caubet 1985.

124. Pour la distinction, voir Yon, Caubet 1985, p. 53. 
21. Inv. 1880/7-10/26 (Fig. 26). H. cons. 21,5 ; diam. base 4,6. Col cassé. Alabastre en gypse.

Ce type de vase est extrêmement commun à Chypre, en particulier dans les niveaux classiques, mais il est attesté plus largement. De très nombreux exemplaires proviennent de nécropoles, et à Salamine, le bûcher du tumulus 77 (dit « cénotaphe de Nicocréon », fin $\mathrm{IV}^{\mathrm{e}} \mathrm{s}$.) en contenait vingthuit en terre cuite, peints ou recouverts d'une pellicule d'or ${ }^{125}$. À Kition même, plusieurs exemples en gypse ont été recueillis dans les niveaux classiques et hellénistiques des fouilles françaises de Bamboula ${ }^{126}$.

22. Inv. 1880/7-10/27 (Fig. 27). H. cons. 6,5. Amphore miniature en gypse, avec un pied haut marqué d'un cordon, un corps piriforme, un cordon entre l'épaule horizontale et le col. Col cassé, pied ébréché. Restes d'anses horizontales fixées sur l'épaule.

Plusieurs fragments d'amphores en albâtre égyptien ont été recueillis parmi le matériel de tombes du Bronze Récent dans le sondage L-N 13 fouillé par la mission française sur la colline de Bamboula ${ }^{127}$. L'exemple du British Museum est plus récent : il imite la forme d'amphores grecques et se rapproche de petits amphorisques d'albâtre découverts dans des tombes hellénistiques d'Amathonte ${ }^{128}$.

Le dernier objet de gypse est sans doute un bouchon.

23. Inv. 1880/7-10/28 (Fig. 28). H. 4,9 ; diam. 3,1. Bouchon en gypse composé d'un élément cylindrique avec des rainures, surmonté d'un élément conique s'évasant vers le haut.

Newton proposait d'interpréter cet objet comme le bouton de préhension d'une pyxide. Mais la partie cylindrique paraît trop longue pour que ce soit le cas. On pensera plutôt à un bouchon, de date peut-être hellénistique. Les bouchons étaient souvent de forme plus simple, en terre crue ou en plâtre ${ }^{129}$.

\section{Métal}

Les trouvailles métalliques, toutes en bronze, sont peu nombreuses : elles comprennent une lampe et des clous, auxquels il faut ajouter vingt monnaies «mostly illegible or late Byzantine », selon Newton, et dont la localisation actuelle est inconnue ${ }^{130}$.

125. V. Karageorghis, Excavations in the Necropolis of Salamis III, Nicosie, 1973, p. 197, pl. CC-CCIV.

126. J.-F. Salles, Kition-Bamboula II. Les égouts de la ville classique, Paris, 1983, p. 107 ; J.-F. Salles, M.-J. Chavane dans Salles 1993, p. 336-337.

127. Yon, Caubet 1985, p. 53-56.

128. M.-J. Chavane, La nécropole d'Amathonte IV. Les petits objets, ÉtChypr XII, Nicosie, 1990, p. 81-82, pl. XIX.

129. Pour un exemple de Bamboula en plâtre, voir J.-F. Salles, M.-J. Chavane, dans Salles 1993, p. $339, n^{\circ} 848$.

130. On doutera toutefois de la datation tardive proposée par Newton, le site n'ayant guère livré de monnaies entre l'époque romaine et l'époque moderne : voir O. Callot, dans Salles 1993, p. 47-59. Le constat est semblable à Kition-Kathari : O. Callot, dans Karageorghis 2005, p. 326. D'ailleurs, le rapport publié dans The Graphic mentionne seulement des « monnaies ptolémaïques en bronze » (cité par Bailey 1969, p. 56, note 11). Je remercie Thomas Kiely d'avoir attiré mon attention sur cette mention. 
24. Inv. 1880/7-10/53 (Fig. 29). H. 2,4 ; diam. 6,2. Lampe en bronze à un bec, cassée sur un côté ${ }^{131}$.

Publ. : Bailey 1996, p. 58, Q 3766 et pl. 69.

Les lampes en bronze sont beaucoup moins communes que les lampes en terre cuite. D'après le rapport de Sinclair, la plupart des lampes de terre cuite découvertes sur la Bamboula étaient en forme de coupelle pincée. C'est le type le plus fréquent à Chypre jusqu'à la fin de l'époque classique. C'est aussi le type le plus fréquent en métal au Bronze Récent et à l'Âge du Fer ${ }^{132}$. L'absence de lèvre étalée de l'exemple du British Museum invite sans doute, comme le suggérait D. Bailey, à le rattacher à un autre type et à le dater au plus tôt de l'époque romaine.

25. Inv. 1880/7-10/54, 55, 56, 57, 59. Fig. 30. Cinq clous en bronze ${ }^{133}$, à corps de section carrée ou ronde et tête plus ou moins aplatie. L. du plus grand 34 ; L. du plus petit 15,3 .

Il est impossible de dater précisément ces clous. On remarquera qu'un bon nombre de clous similaires a été recueilli lors des fouilles suédoises et françaises ${ }^{134}$.

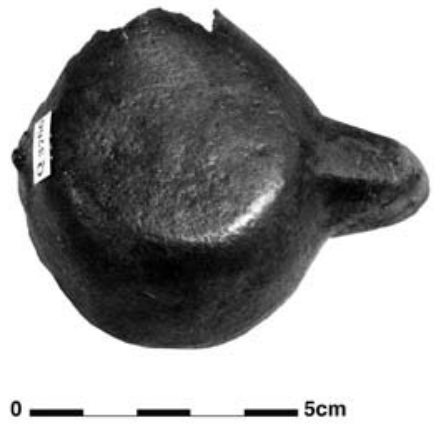

Figure 29. Cat. $24=$ $1880 / 7-10 / 53$.

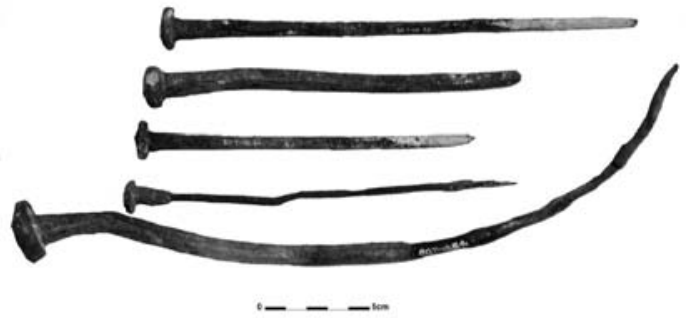

Figure 30. Cat. $25=$ $1880 / 7-10 / 54,55,56,57,59$.

\section{Autres}

Parmi les objets conservés au British Museum figure encore un fragment de fritte ou de faïence.

26. Inv. 1880/7-10/65. H. 1 ; L. 2,2 ; ép. 1 ,8. Objet de forme irrégulière, aplati ${ }^{135}$.

131. S'agit-il du « copper basin beautifully oxidized» du rapport de Sinclair ? L'objet n'est pas répertorié dans la liste dressée par Newton pour les Trustees du British Museum.

132. H. Matthäus, Metallgefässe und Gefässuntersätze der Bronzezeit, der geometrischen und archaischen Periode auf Cypern, Munich, 1985, p. 267-277, pl. 80-83.

133. Le clou inv. 1880/7-10/58, qui appartient au même lot, n'a pas été retrouvé.

134. Gjerstad et al. 1937 , p. $40, \mathrm{n}^{\circ} 292$; p. $51, \mathrm{n}^{\circ} 554$ et 565 ; p. $52, \mathrm{n}^{\circ} 578$; p. 53 , n 599 . J.F. Salles, M.-J. Chavane, dans Salles 1993, p. 334.

135. «A lump of blue colour» (inv. 1880/7-10/65) selon l'inventaire de Newton. 
Il reste enfin à mentionner quatre coquillages ${ }^{136}$ qui devaient appartenir au sédiment naturel (ils sont nombreux dans le sol de cette zone qui était, dans l'Antiquité, ouverte sur la mer).

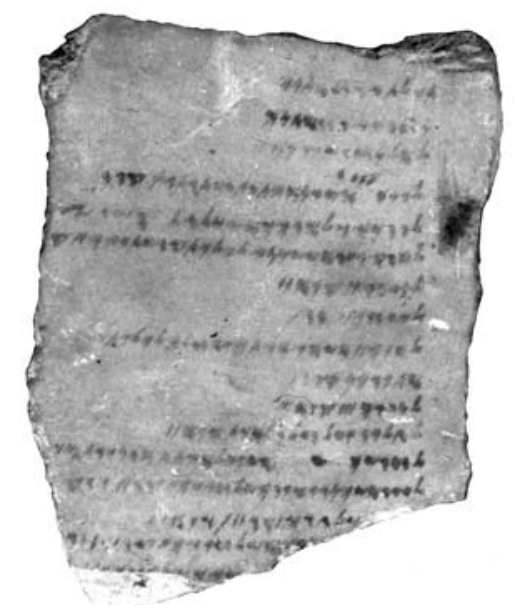

Figure 31. Inv. 1880/7-10/43= BM 125.080. Face A.

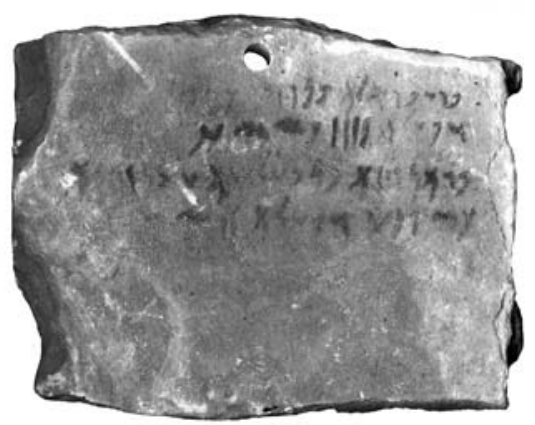

Figure 32. Inv. 1880/7-10/44 = BM 125.081 .

\section{Épigraphie}

Les deux objets les plus connus de la collection de Bamboula au British Museum sont sans conteste les deux plaquettes de gypse à inscription phénicienne (inv. 1880/710/43 et 44 : Fig. 31-32). Ces textes difficiles ont été étudiés à de nombreuses reprises et je me contenterai donc de renvoyer à l'édition du corpus de Kition, qui donne la bibliographie récente ${ }^{137}$. Il s'agit, comme l'avait déjà bien noté Pierides, de comptesrendus de dépenses effectuées par une autorité, d'enregistrement de salaires versés ${ }^{138}$. Les ostraca à contenu économique et administratif sont nombreux parmi les textes phéniciens découverts à Bamboula ${ }^{139}$. C'est une pratique comptable qui n'est pas attestée ailleurs, sauf dans le palais d'époque classique d'Idalion, qui a livré de nombreuses plaquettes inscrites en phénicien et, dans une moindre mesure, en grec syllabique. On remarquera d'ailleurs qu'une des tablettes de calcaire inscrites en grec d'Idalion porte mention,

136. Les coquillages figurent dans les registres (inv. 1880/7-10/61 à 64). Ils ont été déposés au Département de Géologie, dont les collections sont aujourd'hui conservées au Museum d'Histoire Naturelle de Londres.

137. M.-G. Amadasi dans Yon 2004, n ${ }^{\text {os }} 1078$ et 1079.

138. On notera que l'interprétation de l'amateur Pierides, mentionnée par Sinclair dans son rapport («accounts of wages»), est plus exacte que celle du spécialiste Birch, évoquée par Newton (« these lines contain a list of objects, and possibly a date »).

139. M. Sznycer, dans Yon 2004, p. 217-221. 
comme le «tarif » de Bamboula, d'une rétribution versée à des « gardiens des portes (ou des verrous) $\gg{ }^{140}$.

L'absence de contexte précis rend difficile toute conclusion générale à propos de la collection d'antiquités récoltée lors du démantèlement de la Bamboula en 1879, et présentée au British Museum par le comte Granville en 1880. La palette chronologique que ces objets illustrent semble en tout cas recouper la durée d'occupation du site, entre le Bronze Récent et la période romaine. Le seul objet datable du Chypriote Récent III - le modèle de baignoire en pierre - faisait certainement partie d'un mobilier funéraire, ce qui fournit une nouvelle indication de la présence de tombes du Bronze Récent dans cette zone. Certains lots d'objets entrent dans des séries bien connues du site (ainsi les figurines représentant une dea gravida); d'autres sont uniques (ainsi le fragment de sculpture en marbre). Ils témoignent de la variété du matériel qui composait le «mound of rubbish» au moment de sa destruction, tout autant que des goûts des amateurs occidentaux à la fin du XIX ${ }^{\mathrm{e}}$ siècle.

\section{British Museum, Department of Greek and Roman Antiquities}

HISOMA, Université Lyon-2 - CNRS

Photos de T. Kiely et S. Fourrier, sauf mention contraire.

\section{BIBLIOGRAPHIE}

BaILEy (D.M.), 1969, « The Village Priest's Tomb at Aradippou in Cyprus », The British Museum Quaterly 34, p. 36-57.

BAILEY (D.M.), 1996, Catalogue of the Lamps in the British Museum IV. Lamps of Metal and Stone, and Lampstands, Londres.

BuchHolz (H.G.), 1989, « Max OhnefalschRichter als Archäologe auf Zypern », CCEC 11-12, p. 3-27.

Buchiolz (H.G.), 2010, Tamassos I. Die Nekropolen I, II und III, AOAT 48/1, Münster.

Calvet (Y.), 1972, Salamine de Chypre III. Les timbres amphoriques (1965-1970), Paris.

Calvet (Y.), 1982, Kition-Bamboula I. Les timbres amphoriques, Paris.

Counts (D.B.), 2009, «From Siwa to Cyprus: The Assimilation of Zeus Ammon in the Cypriote Pantheon », dans D. Michaelides, V. Kassianidou, R.S. Merrillees (éd.), Egypt and Cyprus in Antiquity, Oxford, p. 104-117.
FOURRIER (S.), 2007, La coroplastie chypriote archaïque, TMO 46, Lyon.

Gjerstad (E.), Lindros (J.), SJöQvist (E.), Westholm (A.), 1937, The Swedish Cyprus Expedition III, Stockholm.

Grace (V.R.), 1953, «The Eponyms on Rhodian Amphora Stamps », Hesperia 22, p. 116-128.

Hermary (A.), 1989, Musée du Louvre. Catalogue des antiquités de Chypre, sculptures, Paris.

Ноок (G.), 2009, Britons in Cyprus, 18781894, unpublished $\mathrm{PhD}$ thesis, University of Texas, Austin.

Karageorghis (V.), 1988, « A Stone Statuette of a Sphinx and a Note on Small Limestone Thymiateria from Cyprus », RDAC, p. 89-93, pl. XXVII-XXXI.

Karageorghis (V.), 1995, The Coroplastic Art of Ancient Cyprus, IV. The Cypro-Archaic Period Small Male Figurines, Nicosie.

140. M. Egetmeyer, «Langues et écritures chypriotes : nouvelles perspectives », CRAI 2008, p. $1000-1001$. 
KARAgEORGHIS (V.), 2005, Excavations at Kition VI. The Phoenician and Later Levels, Nicosie.

KB VI : Caubet (A.), Fourrier (S.), Yon (M.), sous presse, Kition-Bamboula VI, Le sanctuaire sous la colline, Lyon.

KIELY (T.), 2010, " Charles Newton and the archaeology of Cyprus », CCEC 40, p. 231-251.

KIELY (T.), forthcoming, "Poachers turned Gamekeepers? The British Museum archaeological agents on Cyprus in the 1890s », dans D. Pilides (ed.), Proceedings of the International Conference on the Tombs of Enkomi (British Museum excavations, 1896), Nicosia, December 2010.

Merrillees, (R.S.), 2005, « Towards a fuller history of the Cyprus Museum », CCEC 35, p. 191-214.

Morgan (T.), 2011, Sweet and Bitter Island, Londres.

Myres (J.L.), 1940-1945, " Excavations in Cyprus, 1913 », ABSA 41, p. 53-96.

Nicolaou (I.), EMPereur (J.-Y.), 1986, « Amphores rhodiennes au Musée de Nicosie », dans J.-Y. Empereur, Y. Garlan (éd.), Recherches sur les amphores grecques, BCH Suppl. XIII, Paris, p. 515-533.

Ohnefalsch-Richter (M.), 1879, « Neue Funde aus Cypern. Die Akropolis von Kition und ein Sanctuarium der syrischen Astarte », Das Ausland, Stuttgart, p. 970-974.

Ohnefalsch-Richter (M.), 1891, Die antiken Cultusstätten auf Kypros, Dissertation Leipzig.

Ohnefalsch-Richter (M.), 1893, Kypros, die Bibel und Homer, Berlin.
Pogiatzi (E.), 2003, Die Grabreliefs auf Zypern von der archaischen bis zur römischen Zeit, Peleus 23, Mannheim - Möhnesee.

Pryce (F.N.), 1931, Catalogue of Sculpture in the Department of Greek and Roman Antiquities of the British Museum, vol. I, part II. Cypriote and Etruscan, Londres.

SAlles (J.-F.) dir., 1993, Kition-Bamboula IV. Les niveaux hellénistiques, Paris.

Sinclair (H.), 1926, Camp and Society, Londres.

Stanley-Price (N.), 2001, « The Ottoman Law on Antiquities (1874) and the founding of the Cyprus Museum », dans Tatton-Brown 2001, p. 267-275.

Tatton-Brown (V.) (ed.), 2001, Cyprus in the $19^{\text {th }}$ Century AD. Fact, Fancy and Fiction, Oxford.

VARnAVA (A.), 2009, British Imperialism in Cyprus 1878-1915. The Inconsequential Possession, Manchester.

Walters (H.B.), 1903, Catalogue of the Terracottas in the Department of Greek and Roman Antiquities, British Museum, Londres.

Yon (M.), 2004, Kition-Bamboula V. Kition dans les textes, Paris.

Yon (M.), 2006, Kition de Chypre, Paris.

YON (M.), 2011, « Kition-Larnaca aux XVIII et $\mathrm{XIX}^{\mathrm{e}}$ siècles », CCEC 41, p. 21-52.

Yon (M.), CAubet (A.), 1985, Kition-Bamboula III. Le sondage L-N 13 (Bronze Récent et Géométrique I), Paris.

Yon (M.), Caubet (A.), 1989, « Ateliers de figurines à Kition », dans V. Tatton-Brown (éd.), Cyprus and the East Mediterranean in the Iron Age, Londres, p. 28-39. 